\title{
Introducción a la contemplación y conocimiento místico de Dios en el «De Trinitate» de san Agustín (Libro VIII)
}

\author{
SEGUNDA PARTE: (Continuación) \\ ESTUDIO ESPECIAL DEL LIBRO $80^{\circ}$ DEL TRATADO \\ «DE TRINITATE»
}

(PL 42,945-960; CCL 50,268-291)

\section{CAPÍTULO $10^{\circ}$ SÍNTESIS GLOBAL DEL LIBRO $80^{\circ}$}

El libro octavo es un puente, un arco tendido entre la regla de la fe y la especulación psicológica, rica en intuiciones geniales del mundo maravilloso del alma ${ }^{1}$. Es una introducción a toda la segunda parte del «De Trinitate» y es más místico que los otros.

Describe los caminos del conocimiento afectivo de Dios, que no excluye, sino pide el conocimiento teórico ${ }^{2}$

Mediante las huellas y vestigios de la bondad divina y, sobre todo, mediante la imagen divina en el alma humana, busca san Agustín en esta segunda parte, remontarse hasta la Trinidad. Recordemos una vez más: Cumple aquí el autor su antiguo deseo: «conocer a Dios y al alma» ${ }^{3}$.

1. Cf. P. Luis ARIAS, Introducción al tratado de la Santísima Trinidad, versión española, 2. ${ }^{\text {a }}$ ed. BAC, Madrid, 1956, p. 56.

2. Cf. P. Agostino Trape, S. Agostino, l'uomo, il Pastore, il Mistico, Editrice Esperienze, 1976, p. 369.

3. Cf. Solil. $1,2,7$ PL 32,872 . 
El mundo agustiniano lleva siempre un vestigio de Dios, Uno y Trino, y la creación entera debe conducir al Creador. El camino que sigue san Agustín es el autoconocimiento y la plegaria. Para el santo Doctor, el alma es la última síntesis de su pensamiento filosófico, teológico y místico.

Comienza el libro octavo haciendo un recuento de lo dicho en los libros anteriores. Es una nueva etapa la que intenta recorrer: «Dijimos en otro lugar»... ${ }^{4}$. «Decimos que en esta Trinidad dos o tres personas no son superiores a una de ellas» ${ }^{5}$.

Los caminos que sigue san Agustín para conocer a Dios son: la verdad, capítulos primero y segundo 6; la bondad, capítulo tercero 7; la justicia, capítulos sexto y noveno, y el amor o caridad, capítulos cuarto -introductorio-, y los capítulos quinto, séptimo, octavo y décimo. Los atributos de verdad, bondad, justicia y amor son atributos o realidades supremas, subsistentes en Dios y, por tanto, Dios mismo ${ }^{8}$.

En cuanto a «la verdad», es preciso buscarla en toda su pureza, desprendida de todo pensamiento terreno, alejada de toda imaginación. Por eso dice san Agustín: «¡Oh alma... agobiada por varios y múltiples pensamientos terrenos, comprende, si puedes, cómo Dios es verdad!... Cendales de corpóreas imágenes se interponen en tu pensamiento... Permanece, si puedes, en la claridad inicial del primer rápido fulgor de la verdad» ${ }^{9}$.

El mismo procedimiento se debe seguir para el concepto de «bondad». Es preciso conocer la bondad de las cosas y por qué son buenas, para elevarse, por medio de estos bienes parciales, a la intuición de aquel Bien, que es la misma bondad y que hace buenas todas las cosas ${ }^{10}$. Se deben dejar de lado los determinativos «esto y aquello», que limitan la bondad. Por eso dice san Agustín: «Bueno es esto y bueno aquello; prescinde de los determinativos «esto y aquello» $y$ contempla el Bien puro, si puedes; entonces verás a Dios, Bien imparticipado, Bien de todo bien»" $"$.

4. Cf. $D T 5,11$, PL $918-919$ sobre los términos absolutos y relativos; $6,2,3$ y 7,2,3 PL 924s-936, etc., 7,4,9 y 7,6,12; v. Prooemium 1 PL 946s.

5. «Dicimus enim non esse in hac Trinitate maius aliquid duas aut tres personas quam unam earum», DT 8,1,2 PL 42,947.

6. PL id. 947-949.

7. PL id. 949-951.

8. PL id. $953-956$ y $959-960$.

9. «Ecce vide, si potes, o anima... onusta terrenis cogitationibus multis et variis; ecce vide, si potes: Deus veritas est... Ecce in ipso primo ictu quo velut coruscatione perstringeris, cum dicitur: 'Veritas', mane si potes», DT 8,2,3 PL 42,949.

10. Cf. P. TRAPE, Introduzione Teologica al De Trinitate, Opera omnia di S. Agostino, v. IV, Roma 1973, Nuova Biblioteca Agostiniana, Editrice Città Nuova, p. L.

11. «tolle hoc et illud, et vide ipsum bonum, si potes; ita Deum videbis, non alio bono bonum, sed bonum omnis boni», DT 8,3,4 PL 949. 
San Agustín dedica a la «justicia» los capítulos sexto y noveno ${ }^{12}$ del libro octavo. El Santo aborda la posibilidad de conocer la justicia en aquel que no es justo. Afirma que el único medio de conocer la justicia es «en nosotros mismos, dentro de nosotros mismos» y que se debe buscarla, por tanto, en la interioridad ${ }^{13}$. Concluye afirmando que únicamente se debe amar a los hombres o porque son justos-semejantes al supremo modelo de justicia- o para que sean justos, para que se conformen al modelo ${ }^{14}$. Lo mismo hay que decir del amor a sí mismo, para que sea verdadero amor.

De nuevo afirma en el capítulo noveno que el concepto de justicia hay que buscarlo «en lo íntimo de nosotros mismos, por encima de nosotros, en la misma verdad» ${ }^{15}$.

Podemos amar a los justos, «porque los justos han conformado su vida a este ideal supremo mientras vivieron en su carne mortal» ${ }^{16}$. Parece aludir aquí san Agustín a este ideal, enclavado en lo más hondo del alma, ideal de justicia y santidad, que es Cristo, que permanece fijo, inconmutable a nuestra mirada, en nuestro interior.

Pero la mayor parte del libro octavo la dedica san Agustín al conocimiento de Dios por el «amor». Directa o indirectamente, tratan del amor los capítulos cuarto, quinto, séptimo, octavo y décimo. El capítulo cuarto es una especie de introducción, un preámbulo del amor ${ }^{17}$, es decir, el papel que representa la fe en el amor. "A Dios, dice, hay que amarlo por la fe; de otra manera el corazón no puede ser purificado ni hacerse idóneo para la visión» ${ }^{18}$. «Se debe evitar, añade, que el alma, cuando cree algo que no ve, se finja algo ficticio o irreal y espere y ame lo que es falso» ${ }^{19}$. Esto sólo se puede conseguir por la fe, que «no se ocupa del óvalo facial y de los contornos somáticos de los personajes, sino de la vida íntima que llevaron» ${ }^{20}$.

El capítulo quinto trata de la posibilidad de amar a la Trinidad sin conocerla ${ }^{21}$. Una serie de reflexiones lleva también a san Agustín a la afirma-

12. PL 953-956.

13. «In nobis igitur novimus quid sit iustus... Non alibi hoc invenii... nisi apud meipsum... apud seipsum quaerit quid respondeat», DT 8,6,9 PL 954.

14. «aut quia iusti sunt, aut ut iusti sint, amare debet», DT 8,6,9 PL 956.

15. «intus apud nos, vel potius supra nos in ipsa veritate conspicimus», $D T 8,9,13$ PL 959 .

16. «quia eius vitam, cum in carne viveret, huic formae coaptatam et congruentem fuisse, fide retinemus», $D T 8,9,13$ PL 42,960.

17. PL 951-952.

18. «nisi per fidem diligatur, non poterit cor mundari, quo ad eum videndum sit aptum et idoneum», $D T$ 8,4,6 PL 951.

19. «cavendum est, ne... fingat sibi aliquid quod non est», DT 8,4,6 PL 951.

20. «Neque ibi occupatur fides nostra, qua facie corporis fuerint illi homines; sed tantum quia per Dei gratiam ita vixerint», DT 8,4,7 PL 951.

21. PL 952-953. 
ción de que es indispensable la fe para un auténtico amor. «Antes de entender es necesario creer», por eso se ha de «vigilar para que nuestra fe no sea fingida» ${ }^{22}$. Y más adelante: «Creemos que existe la Trinidad..., no amamos una Trinidad cualquiera, sino la Trinidad que es Dios» ${ }^{23}$.

En el capítulo séptimo ${ }^{24}$ define san Agustín qué es el auténtico amor: «Es vivir justamente adheridos a la verdad y dejar todo lo perecedero por amor a los hombres, a quienes deseamos vivan justamente» ${ }^{25}$. Implica, por tanto, el amor - asegura en el capítulo octavo- ${ }^{26}$, la adhesión a la verdad, como base para que sea auténtico y, como consecuencia de esta adhesión a la verdad, dejar todo lo perecedero por amor a los hombres. Es el amor verdadero el que incluye necesariamente el amor a Dios. Es más, «se conoce mejor el amor a Dios que impulsa al amor, que el amor al hermano a quien ama... Dios es más conocido porque está más presente, porque es más íntimo en nosotros... porque es más cierto» ${ }^{27}$.

A continuación ofrece el Santo una segunda definición, que es al mismo tiempo la consecuencia necesaria del verdadero amor: «Es el amor el que nos une con vínculo de santidad a todos los ángeles buenos y a todos los siervos de Dios; nos une a ellos y nos somete a Él» ${ }^{28}$.

Para san Agustín, por tanto, no puede hablarse con justedad de amor, sin que implique el recuerdo y la presencia del amor mismo, que es Dios. El conocimiento del amor es el conocimiento de Dios, es el conocimiento de la Trinidad, que es Dios. Por eso dice a continuación: «Dirás, veo la caridad y la contemplo... mas cuando reflexiono en el amor no descubro la Trinidad» ${ }^{29}$. San Agustín da luego la solución: «Ves la Trinidad si ves el amor» ${ }^{29 a}$.

En el capítulo décimo ${ }^{30}$, finalmente, demuestra que el amor es imagen de la Trinidad: «He aquí, pues, tres realidades: el que ama, lo que se ama y el amor» ${ }^{31}$.

22. «prius autem quam intellegamus credere debemus, vigilandumque nobis est, ne ficta sit fides nostra», $D T$ 8,5,8 PL 42,952.

23. «Hoc ergo diligimus in Trinitate, quod Deus est», DT 8,5,8 PL 953.

24. PL id. 956-957.

25. «Haec est autem vera dilectio, ut inhaerentes veritati iuste vivamuś: et ideo contemnamus omnia mortalia (temporalia), prae amore hominum, quo eos volumus iuste vivere», $D T$ 8,7,10 PL 956.

26. PL id. 957-959.

27. «Deum... plane notiorem, quia praesentiorem; notiorem, quia interiorem; notiorem, quia certiorem», $D T 8,8,12$ PL 957.

28. «Ipsa est dilectio quae omnes bonos angelos, et omnes Dei servos consociat vinculo sanctitatis, nosque et illos coniungit invicem nobis et subiungit sibi», DT 8,8,12 PL 957.

29. «caritatem video... sed cum illam video non in ea video Trinitatem», DT 8,8,12 PL 958.

29a. Ib.

30. PL 960.

31. «Ecce tria sunt: amans, et quod amatur, et amor», DT 8,10, 14 PL id. 960. 
Pero el santo Doctor quiere llevar a sus lectores a la contemplación de Dios. Por eso anota: «¿Qué es el amor, sino vida que enlaza o anhela enlazar dos vidas, a saber, el amante y el amado?» ${ }^{32}$.

Hay una jerarquización progresiva en las analogías de la Trinidad que va a emplear san Agustín. Por esto dice: «Tenemos aquí -en el amor al amigotres cosas: el amante, el amado y el amor». Y significativamente dice al terminar el libro: «Réstanos remontarnos aún más arriba y buscar estas tres realidades, en la medida otorgada al hombre. Pero descanse aquí un momento nuestra atención... porque... hemos topado ya con el soto donde es menester buscar» ${ }^{33}$.

Y finaliza así el libro octavo: "Que esto baste y sirva de exordio a cuanto en lo sucesivo hayamos de entretejer» ${ }^{34}$. Lo que ha de entretejer, para buscar la imagen de la Trinidad, es precisamente el objeto de la segunda parte del tratado «De Trinitate».

\section{CAPÍTUlo $2 .^{\circ}$ CONOCIMIENTO MÍSTICO DE DIOS}

\section{Introducción}

Conocimiento místico quiere decir vivencia y experiencia amorosa de Dios. Todo ello incluye una vida entera, el ser y la actividad total del hombre. Para alcanzar la fe y la razón se debe partir de la vida cristiana, una e indivisible, que abarca la filosofía, la teología y la mística. Filósofo auténtico «es el que ama a Dios» ${ }^{1}$ y perfecto filósofo es aquel que lo posee, porque tendrá la sabiduría perfecta, que es la meta de la bienaventuranza. Es decir, no es sólo adherir intelectualmente a una verdad para propia satisfacción, sino sosegar la aspiración del corazón hacia el Dios vivo, al que se llega á tocar por la fe, la esperanza y el amor.

La caridad, comunión inefable del Padre y del Hijo, produce en nosotros el amor, la delectación en la divinidad presente, el gozo de la posesión ${ }^{2}$.

El método teológico empleado por san Agustín, en la segunda parte del

32. «Quid est ergo amor, nisi quaedam vita duo aliqua copulans, vel copulare appetens, amantem scilicet, et quod amatur», DT 8,10,14 PL id. 960 .

33. «iam inventum est ubi quaeratur», $D T$ ib.

34. DT $i b$.

1. «verus philosophus est amator Dei, De civ. Dei 8, 1 PL 41,225; ib., 8,8 PL 41,233.

2. Cf. P. Argimiro TurRado, La Sma. Trinidad en la vida espiritual del justo, su templo vivo, según san Agustín, Revue des Etudes Augustiniennes, 1959, segunda parte, p. 228. 
tratado «De Trinitate» especialmente, se explica por el fin perseguido, que es menos demostrar a Dios que mostrarle. Todo el estudio en el gran tratado está, en último término, en función del conocimiento místico ${ }^{3}$. Dios es la Verdad y el Bien, y no puede dar al hombre más que bien. Dios es la Sabiduría infinita y comunica la sabiduría por medio de sus relaciones con las criaturas, principalmente por el conocimiento y la voluntad de todo el orden del universo, que se halla sintetizado en la criatura racional ${ }^{4}$. El hombre, inteligente y libre, puede llegar a la verdad y unirse al bien. Esta realidad de Dios en el hombre puede obscurecerse y deformarse, pero no desaparece jamás. Por medio de la gracia, esa vivencia se restituye y aparece de nuevo en todo su esplendor.

Por el conocimiento, el hombre, directa o indirectamente, se halla siempre referido a Dios, porque la mente, imagen de Dios, siempre se recuerda, se conoce y se ama ${ }^{5}$.

La plegaria final del tratado nos deja ver la acentuación mística de toda la obra: «Líbrame, Dios mío, de la muchedumbre de palabras que padezco en mi alma, acogida a tu misericordia» ${ }^{6}$.

RESUMEN ESQUEMÁTICO DEL «LIBRO $8 .^{\circ} \gg$

1. Prólogo

2. ${ }^{\circ}$ Conocimiento místico de Dios por los siguientes conceptos:

1.- Concepto de Verdad

2.- Concepto de Bondad

3.- Concepto de Justicia

4.- Concepto de Caridad.

Prólogo

Estudiaré en esta segunda parte, de modo especial, los conceptos de verdad, bondad, justicia, caridad, en los cuales, sintéticamente, se resume el libro octavo. La primera afirmación de san Agustín es su fe en la «unidad de esen-

3. Cf. P. Agostino TraPe, Introduzione al De Trinitate, Opera Omnia di S. Agostino, v. IV, Roma 1973, p. XLIII.

4. Cf. CAYre, La Contemplatio Augustinienne, Principes de Spiritualité et de Théologie, 1954, p. 256.

5. Cf. $D T 14,14,18$ PL 1049.

6. «Libera me, Deus, a multiloquio quod patior intus in anima mea, misera in conspectu tuo, et confugiente ad misericordiam tuam», DT 15,28,51 PL 1098. 
cia y en la trinidad de Personas» ${ }^{1}$. Los siete primeros libros tratan de la unidad de esencia y de la acción en las Personas divinas. Esta unidad de esencia y de acción es verdad válida contra el modalismo: tres modos distintos en Dios; contra el triteísmo: tres dioses, confusión entre naturaleza e hipóstasis; contra el arrianismo: el Verbo, para el arrianismo, no es consubstancial al Padre. San Agustín afirma la unidad de esencia y trinidad de Personas ${ }^{2}$. El santo Doctor contesta a todas las dificultades con argumentos de la Escritura y de la tradición en general, en la primera parte ${ }^{3}$; con argumentos de razón, en la segunda parte del gran tratado. El libro octavo, recordemos, es punto de enlace entre la primera y la segunda parte. Comienza san Agustín en el prólogo haciendo una referencia a los libros anteriores, especialmente al libro quinto, donde estudia las relaciones divinas.

\section{Puntos fundamentales:}

1. «Dijimos en otro lugar cómo en la Trinidad los nombres que entrañan mutua relación se aplican propia y distintamente a cada una de las divinas Personas» ${ }^{4}$.

El concepto de persona lo explica san Agustín con la categoría lógica de relación ${ }^{5}$. La doctrina de las relaciones la reconocerá más tarde la Iglesia como suya ${ }^{6}$. En el libro quinto afirmaba: «En Dios nada se afirma según accidente... no obstante, no todo cuanto de Él se enuncia se dice según la substancia. Se habla a veces de Dios según la relación «ad aliquid». La relación en Dios no es accidente, porque no es mudable, no hay mutación alguna ${ }^{7}$. La teoría de las relaciones ofrece solución a las dificultades para comprender el misterio. San Agustín la enraíza en la Escritura y en la tradición. Conoce los escritores católicos anteriores a él ${ }^{8}$.

En rigor, la relación según san Agustín, exigiría una categoría propia en la primera división del ser metafísico: substancia, accidente y relación. Es de-

1. «quod Trinitas sit unus et solus et verus Deus», $D T 1,2,4$, PL 822 .

2. Cf. José MORÁN, Las relaciones divinas, según san Agustín, Augustinus IV, 1959, p. 354; cf. Sermo 103,3 PL 38,614s; Ench. 9,3 PL 40, 335; De doctr. chris. 1,5,5 PL 34,21.

3. Cf. estos lugares donde se ocupa especialmente de la unidad de acción y operación de las tres divinas personas, DT 1,5,8 PL 824; 1,6,12 PL 827; 1,18,17 PL 831; 1,12,25 PL 838 y 4,21,30 PL 900ss.

4. «diximus alibi», DT 8 prooemium, PL 946-947.

5. «quod habet, hoc est, excepto quod relative quaeque persona ad alteram dicitur», De civ. Dei $11,10,1$ PL 41,325 .

6. Conc. Flor. Decretum pro Iacobitis, «In Trinitate omnia sunt unum, ubi non obviat relationis oppositio», Denz 703 y 1330.

7. «quod tamen relativum non est accidens, quia non est mutabile», $D T$ 5,5;6 PL 42,914.

8. Cf. $D T 1,3,5$ PL 822; $1,6,13$ PL 827; 1,7,14 PL 828s. 
cir, ser subsistente, ser inhesivo, ser relativo ${ }^{9}$. El Santo afirma que ha leído «cuantos escritores o intérpretes católicos, anteriores a él, en la especulación sobre la Trinidad», tuvo a disposición ${ }^{10}$.

No sabemos si aquel «omnes quos legere potui» hace referencia también a los Padres griegos. El P. Arias se inclina a que san Agustín conocía la monografía de san Ambrosio sobre el Espíritu Santo y el «De Spiritu Sancto» de Dídimo el Ciego, como los escritos de los Capadocios contra los pneumamatómacos del siglo IV ${ }^{11}$. Las obras que san Agustín cita de los Padres griegos estaban ya traducidas, v.gr. «De Principiis», de Orígenes ${ }^{12}$, «De Spiritu Sancto» de Dídimo el Ciego ${ }^{13}$. Es fácil que los conociera, pero en su traducción, por lo que su influjo sería sólo indirecto ${ }^{14}$. Parece deducirse; de todos modos, que el mismo san Agustín reconoce que ha dado un gran avance sobre sus antecesores ${ }^{15}$. Aquel «omnes quos legere potui» parece indicar en el santo doctor el deseo de tener las fuentes, que hubieran facilitado su trabajo. La doctrina de las relaciones aparece sólo implícitamente en los símbolos anteriores a san Agustín ${ }^{16}$.

2. «Lo que cada uno es respecto de sí mismo no se ha de expresar en plural, pues son uno, la misma Trinidad» ${ }^{17}$.

Habla ahora san Agustín de los atributos absolutos. Los atributos absolutos «se refieren a la esencia» ${ }^{18}$. Es decir, «todo lo que significa existencia absoluta y no habitud mutua... se refiere a la esencia». Por tanto, se han de afirmar en singular. Es decir: Los términos absolutos son comunes a las tres divinas Personas en Dios; los relativos, en cambio, son propios de cada Persona.

En Dios se han de distinguir las perfecciones absolutas que se refieren a la esencia — «dicitur ad se»-, de las perfecciones relativas, «dicuntur ad

9. Cf. versión española, Tratado sobre la Santísima Trinidad por el P. Luis Arias, BAC 1956, p. 403 nota 5.

10. «Omnes quos legere potui, qui ante me seripserunt de Trinitate, quae Deus est». DT 1,47 PL 824; v. J. MORÁN, o.c., p. 367.

11. Cf. $D T 1,6,13$, Versión española P. Arias, nota, 6, p. 149.

12. Cf. De civ. Dei, $11,23,1$ PL 41,336 .

13. Cf. Quaest. in Hep. 11,25 PL 34,604.

14. Cf. José MorÁN, o.c., pp. 370-371.

15. Cf. $D T$ 1,5,8 PL 824s; ib. 2 prooemium PL 835; 3 prooemium, 1 PL 868; 3,10,21 PL 881 , etc.

16. Símb. de los Apos. cf. DB 1-13; Niceno, DB. 54. etc.

17. «Quod vero ad se dicuntur singuli, non dici pluraliter tres sed (unam) ipsam Trinitatem», $D T$ 8, prooemium PL 947.

18. «et quidquid alius non ad invicem relative, sed ad se singuli dicuntur. Hoc enim secundum essentiam dicuntur», $D T 8$, prooemium PL ib. 
alium». En el libro quinto había dicho: «quede sentado como fundamental que todo cuanto en aquella sublimidad se refiere a sí misma es substancial, y cuanto de ella dice proyección a otro término no es substancia, sino relación» ${ }^{19}$. En esta relación — «ad aliud»- no hay accidente alguno, porque no hay mutabilidad.

El «Hijo es siempre Hijo y nunca principia a ser Hijo» ${ }^{20}$. Lo mismo ha de afirmarse para explicar la relación en el Espíritu Santo. Sucede a veces, sin embargo, que «para expresar la relación mutua entre el Padre y el Hijo y el Espíritu Santo, nos falta la palabra correlativa» ${ }^{21}$.

\section{3. «...un Dios, bueno y omnipotente, que es la Trinidad» ${ }^{22}$}

Esta unidad de esencia, de atributos absolutos, lleva consigo que, «con relación a las criaturas, el Padre y el Hijo y el Espíritu Santo son un solo principio, como uno es el Creador y uno el Señor» ${ }^{23}$. Defiende este principio san Agustín en el tratado «De Trinitate» y en muchísimos lugares de sus obras ${ }^{24}$.

En resumen: «Toda distinción hipostática consiste en la mutua relación de las divinas Personas, relación que discrimina y une, porque lo relativo es inexplicable sin los términos de relación» ${ }^{25}$.

4. Cada Persona tiene la plenitud de substancia, de bondad, verdad, etc. $y$ de cualquier otro atributo absoluto

Por esto «se puede decir tres personas o tres substancias» siempre que no se entienda diversidad de esencia ${ }^{26}$.

En cuanto al término «persona», en sentido propio, para aplicarlo a la trinidad debería reunir estas condiciones:

a.- Indicar relación, porque la relación es precisamente la razón de la distinción en las Personas divinas; b.- indicar relación propia incomunicable, que constituyen las Personas en su individualidad ${ }^{27}$.

19. «teneamus, quidquid ad se dicuntur praestantissima illa et divina sublimitas, substantialiter dici; quod autem ad aliquid, non substantialiter, sed relative», DT 5,8,9 PL 916-917.

20. «semper natus est Filius», DT 5,5,6 PL 914.

21. «In multis enim relativis hoc contigit, ut non inveniatur vocabulum, quo sibi vicissim respondeant quae ad se referuntur», DT 5,12,13 PL 919.

22. «unus Deus, bonus, omnipotens ipsa Trinitas», DT 8 prooemium PL 947.

23. «Ad creaturam vero Pater, et Filius, et Spiritus sanctus unum principium, sicut unus Creator et unus Dominus», DT 5,14-15 PL 921.

24. Cf. De vera rel. 7,13 PL 34,128; De Gen. ad litt. imp. 1,2 PL 34, 221; De Gen ad litt. 9,15,26 PL 34,402; De an. et eius or., 2,3,5 PL 44, 496; Ench. 10,3 PL 40,236, etc.

25. Cf. P. ARIAS, Introducción, p. 43.

26. «Ideoque dicit tres personas, vel tres substantiae, non ut aliqua intellegatur diversitas essentiae», DT 8, prooemiun PL 947.

27. Cf. P. TRAPÈ, Introduzione», p. XXXVI. 
El término «persona» no reúne para san Agustín estas condiciones. Persona indica más bien una perfección absoluta que relativa; «en Dios una misma cosa es ser y ser persona» ${ }^{28}$.

San Agustín observa que el término persona indica perfección absoluta, es decir, indica un sujeto concreto, incomunicable. Más adelante se pregunta: «¿Por qué razón una esencia se ha de subdividir en tres substancias o personas»? ${ }^{29}$. Y él mismo nos responde: «Buscó la pobreza - humana-cómo expresar estas tres cosas, y las llamó substancias o personas... dando a entender la unidad al poner en Dios una esencia, y la Trinidad al distinguir tres substancias o personas» ${ }^{30}$.

En resumen: san Agustín anota que el término persona indica perfección absoluta. «Solamente la pobreza del lenguaje humano y el uso eclesiástico ha aplicado este término para indicar las relaciones en la Trinidad ${ }^{31} \mathrm{y}$ para responder con una palabra al que pregunta quiénes o qué son los tres» ${ }^{32}$.

\section{5. «Igualdad en la Trinidad»}

«Tan grande es la igualdad en esta Trinidad, que no sólo el Padre no es mayor que el Hijo en lo referente a la divinidad, pero ni el Padre y el Hijo juntos son, en algo, mayores al Espíritu Santo; ni cada una de aquellas divinas Personas en particular es inferior a la Trinidad» ${ }^{33}$. Alude aquí al libro sexto, donde dice: «en la Trinidad excelsa, una Persona es igual a las otras dos, y dos no son mayores que una sola de ellas, y en sí son infinitas» ${ }^{34}$.

\section{6. «Por la piedad a la visión»}

«Con devotísima piedad imploremos el auxilio del cielo, para que nuestra inteligencia se abra... y la mente pueda intuir la esencia de aquella verdad inmaterial e inmutable» ${ }^{35}$

28. «non aliud est Deo esse, aliud personam esse, sed omnino idem», $D T$ 7,6,11 PL 943. 944.

29. «Cur ergo una essentia in tres substantias vel personas subdividitur»? $D T 7,6,11 \mathrm{PL}$

30. «quibus nominibus non diversitatem intellegi voluit, sed singularitatem noluit», $D T$ 7,4,9 PL 942.

31. Cf. P. TRAPE, o.c., p. XXXVII.

32. «ut vel uno aliquo vocabulo responderi possit, cum dicitur quid tres, vel quid tria», $D T$ 8 prooemium PL 947.

33. «tantamque esse aequalitatem in ea Trinitate, ut non solum Pater non sit maior quam Filius, quod attinet ad divinitatem, sed nec Pater et Filius simul maius aliquid sint quam Spiritus sanctus, aut singula quaeque persona quealibet trium minus aliquid sit quam ipsa Trinitas», $D T 8$ prooemium, PL 947.

34. «in illa Trinitate tantum est una quantum tres simul» etc., DT 6,10,12 PL 932; el mismo concepto se halla en $D T 7,6,11$ PL 943 s., etc.

35. «Deo suplicandum devotissima pietate, ut intellectum aperiat» $i b ., 8$, prooemium. 
Al principio del tratado había dicho: «La piedad... sane la flaqueza de la inteligencia y se pueda percibir la verdad inconmutable» ${ }^{36}$. $Y$ en el libro sexto: «...El que aún no ve, camine por la piedad a la visión» ${ }^{37}$. Sobresale este concepto de «piedad y plegaria» en todo el tratado «De Trinitate». Se halla al principio, al final de la obra y se halla entreverada en cada página, como quedó anotado en el aspecto místico del presente estudio.

\section{Modo interiore»}

«Hemos de estudiar de un modo más íntimo que en los libros precedentes» ${ }^{38}$, es decir, de modo más profundo, en el interior del alma, donde se puede oír la voz de Dios.

Uniendo este concepto «modo interiore», con aquel «Deo suplicandum devotissima pietate» vienen al recuerdo aquellas palabras de san Agustín en «De magistro»: «Comprendemos... consultando interiormente la verdad que reina en la mente... Y esta verdad que es consultada y enseña, es Cristo, que... habita en el hombre, esto es, la inconmutable Virtud de Dios y su eterna Sabiduría» ${ }^{39}$. Y más claramente todavía: «A Dios se la ha de buscar y suplicar en lo íntimo del alma racional, que es lo que se llama «hombre interior» ${ }^{40}$.

El santo Doctor quiere llevarnos en esta segunda parte por el camino de la interioridad, donde se conoce y se ama a Dios y se conoce la palabra eterna. En las Confesiones nos dice a este propósito, comentando la creación: «Estas palabras tuyas, pronunciadas en el tiempo, fueron transmitidas por el oído exterior a la mente prudente, cuyo oído interior tiene aplicado a tu palabra eterna» ${ }^{41}$. Y de modo más claro todavía: «Amo a mi Dios, luz, voz, fragancia, alimento y amplexo del hombre mío interior... Esto es lo que amo cuando amo a mi Dios» ${ }^{42}$. Quiere, por tanto, san Agustín, desde ahora de modo especial, orientar su investigación y su reflexión por los caminos de la interioridad, valiéndose incluso de los sentidos exteriores. Nos dice, a este propósito, tam-

36. «ut ad perceptionem incommutabilis veritatis imbecillem mentem observata pietas sanet», $D T$ 1,2,4 PL 822.

37. «qui autem non videt, tendat per pietatem ad videndum» DT 6,10,12 PL 932; el mismo concepto en 7,6,11 PL 943s. 947.

38. «modo interiore quam superiora (quam superiore) tractabimus», $D T 8$ prooemeium PL

39. «illi autem qui consulitur, docet, qui in interiore homine habitare dictus est Christus... sapientiam quam quidem omnis rationalis anima consulit», De mag. 11,38 PL 32,1216.

40. «qui homo interior vocatur», De mag. 1,2 PL 32,1195.

41. «cuius auris interior posita est ad aeternum verbum tuum», Conf. 11,6,8 PL 32,812.

42. «cum amo Deum meum, lucem, vocem, odorem, cibum, amplexum interioris hominis mei... Hoc est quod amo, cum Deum amo», Conf. 10,6,8 PL 32,782-783. 
bién en las Confesiones: «El hombre interior es quien conoce estas cosas por medio del exterior. Yo interior conozco estas cosas; yo, alma, por medio del sentido de mi cuerpo» ${ }^{43}$. Y al final del mismo capítulo: «Tú eres mejor que esto (mejor que las cosas creadas); a ti te lo digo, ;oh alma!, porque tú vivificas la mole de tu cuerpo prestándole vida, lo que ningún cuerpo puede prestar a otro cuerpo. Mas tu Dios es para ti hasta la vida de tu vida» ${ }^{44}$.

\section{8. «Regla de fe»}

«Sin desviarnos de la regla — de fe- para que, si algo no aparece claro a nuestra inteligencia, no lo rechace la firmeza de la fe» ${ }^{45}$.

Había dicho poco antes: «Queden sentadas estas verdades», es decir: diferencia entre los términos relativo y absoluto, igualdad de las tres divinas Personas, piedad y súplica a Dios, etc., para entrar en este nuevo camino y además porque «trataremos ahora las cosas «modo interiore»... para que la «mente pueda intuir la esencia de aquella verdad inmaterial e inmutable» ${ }^{46}$. Esta «regla de la fe», a la que alude aquí, recuerda el esquema del símbolo Quicumque, del que san Agustín anticipa algunas expresiones ${ }^{47}$.

Traza aquí san Agustín, por tanto, a grandes rasgos, el plan de la segunda parte, diseñando la orientación fundamental que ha de tener y que debe tener en cuenta también el que lea la obra.

\section{1) CONOCIMIENTO MÍSTICO DE DIOS POR EL «CONCEPTO DE VERDAD»}

Comprende este apartado dos capítulos: el primero y el segundo del libro octavo del «De Trinitate». Sintetizo previamente, por este motivo, los dos capítulos, de modo global, antes de su explicación respectiva.

43. «ego interior cognovi haec, ego, ego animus per sensum corporis mei», Conf. $10,6,9$ PL 32,783.

44. «tu melior es, tibi dico, anima... Deus autem tuus etiam tibi vitae vita est», Conf. $10,6,10 \mathrm{PL}$ ib.

45. «servata illa regula ut quod intellectui nostro nondum eluxerit, fidei non dimittatur», DT 8, prooemium, PL 947.

46. «quo possit mente cerni essentia veritatis, sine ulla mole, sine ulla mutabilitate», $i b$.

47. Cf. a este propósito P. TRAPE, Introduzione. p. XIX y nota 3 y p. XXVIII, nota 19, comentando $D T 5,8,9$. 


\section{Ideas fundamentales:}

CAPítulo $10^{\circ}$

$\left.1 .^{a}\right)$ En la Trinidad dos o tres Personas no son superiores a una de ellas.

2. $\left.{ }^{a}\right)$ Imposibilidad de comprender la Verdad misma.

3. ${ }^{2}$ ) Lo inteligible e inconmutable no admite grados de verdad.

\section{CAPÍtulo $2 .^{\circ}$}

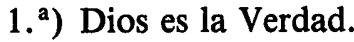

2. $\left.{ }^{a}\right)$ Dios es verdad y es luz.

3. $\left.{ }^{a}\right)$ Medios para conocer la Verdad.

4. ${ }^{a}$ ) Se debe rechazar toda imagen para llegar a la Verdad.

$\left.5 .^{a}\right)$ Debe negarse en Dios todo lo que sea mudable.

6. ${ }^{a}$ ) Insuficiencia de la vía de eminencia para conocer la Verdad.

7. ${ }^{\text {a) }}$ Contemplación de la Verdad.

\section{Consecuencias:}

$1 .^{\mathrm{a}}$ - Los seres creados, verdad limitada.

2. ${ }^{\text {a }}$ Un gran paso, conocer «lo que no es Dios».

3. ${ }^{\mathrm{a}}$ - Los seres creados no pueden darnos la noción de Dios.

4. ${ }^{\mathrm{a}}$ - Peregrinación lejos de Dios.

5. ${ }^{\text {- }}$ La felicidad del hombre, el gozo de la verdad.

\section{CAPítulo $1 .^{\circ}$ A Dios, la Misma VeRdad, SE le halla eN la INTIMIDAD}

San Agustín hace en este primer capítulo una especie de introducción al tema de la verdad, que desarrolla ampliamente en el capítulo segundo.

Es además este capítulo primero, punto de enlace entre el prólogo y el libro octavo propiamente dicho. Señalemos los puntos principales:

1. «Decimos que en esta Trinidad dos o tres Personas no son superiores a una de ellas»

Repite aquí san Agustín el concepto del comienzo del prólogo. En el prólogo era un pasado - «diximus alibi»-, y se refería a los libros anteriores; aquí es un presente - diximus enim»-, y se refiere a la segunda parte, que comienza precisamente aquí ${ }^{1}$.

1. «Dicimus enim non esse in hac Trinitae maius aliquid duas aut tres quam unam», $D T$ 8,1 PL 947. 
Es decir, una vez más san Agustín quiere hacer notar el enlace que existe entre toda la obra, pues este concepto lo hallamos en varios lugares, especialmente en el libro quinto ${ }^{2}$. Quiere dejar bien sentado el concepto de unidad de esencia y de todos los atributos absolutos, y la trinidad de personas, por lo que relativamente se refiere la una a la otra.

2. «Imposibilidad de comprender la Verdad misma, causa eficiente de la creación $\rangle^{3}$

En el libro cuarto afirma que esta verdad es el Verbo, por el que fueron hechas todas las cosas. «Uno es el Verbo de Dios, inconmutable verdad, por quien fueron hechas todas las cosas» ${ }^{4}$. En el comentario a los Salmos nos dice: «Ella - la Sabiduría - es la Verdad, ella es Dios... es el Verbo de Dios, por quien fueron hechas todas las cosas» 5. Cristo es la Verdad, es la Luz de Dios: «Tu luz y tu verdad son dos nombres, pero son una misma cosa... Ambas co-

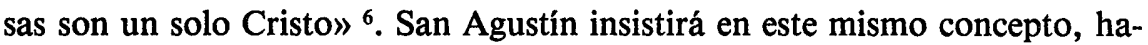
ciendo ver la espiritualidad de la verdad: «Dios es verdad, y la verdad no es cuadrada ni redonda, ni alargada. En todo lugar está presente, si el ojo del corazón está abierto a ella» ${ }^{7}$. Y es porque la verdad únicamente se halla en el corazón. «En poco se ha de tener la verdad, si no se halla en el corazón» ${ }^{8}$. Solamente en el interior se puede oír la verdad. La oímos en el interior, pero hablamos a los que están fuera de nuestro corazón.

Vemos en todo este contexto la insistencia de san Agustín en hacernos ver el rumbo que ha de tomar su reflexión psicológica en esta segunda parte, que ha de centrarse en la presenciabilidad de la Trinidad en el alma, pero en lo más excelso de ella, en lo más interior.

2. Cf. $5,5,6$ PL $813-814 ; 5,7,8$ PL $915-916 ; 5,8,9$, PL 916-917; 5,11,12 PL 918-920; 6,2,3 PL 924; 7,2,3 PL 936-939, etc.

3. «veritatem autem ipsam qua creata sunt non potest intueri», DT 8,1 PL 947.

4. «Unum Verbum Dei est, per quod facta sunt omnia, quod est incommutabilis veritas», DT 4,1,3 PL 888 .

5. «Ipsa est veritas, ipsa est Deus... Verbum Dei est, Sapientia Dei est, per quam facta sunt omnia», En in Ps 33, 2,6 PL 36,310-311.

6. «Ipsa lux tua et veritas tua: haec nomina duo, res una... Et hoc utrumque unus Christus», En in Ps 42,4 PL 36,478.

7. «Veritas Deus, Veritas nec quadrata est, nec rotunda, nec longa. Ubique praesens est, si cordis oculus ad eam pateat», En in Ps 30,2,1,7 PL 36,234.

8. «parum est verum loqui, nisi etiam in corde ita sit», En in Ps 14,3 PL 36,143. 
3. «Todo cuanto es inteligible e inconmutable no admite grados en la verdad, porque es igual e inconmutablemente eterno» ${ }^{9}$.

Los seres son verdaderos en cuanto el entendimiento los puede conocer. Se llaman verdaderos en cuanto dicen relación al entendimiento. Lo inconmutable no admite mayor perfección, porque tiene todas las perfecciones en grado infinito; ni admite tampoco disminución, porque las tiene de modo necesario. El ser infinito dice una connotación infinita a su conocimiento. Por ello, solamente Dios mismo puede conocerse totalmente. San Agustín dice claramente a continuación: El ser «inconmutable no admite grados en la verdad... porque lo grande se identifica allí con la verdadera existencia» ${ }^{10}$.

La consecuencia lógica es que «la grandeza en Dios es la misma verdad» ${ }^{11}$. Se trata de un atributo absoluto, que se identifica con la esencia divina infinita. Y más adelante: "Allí ser mayor es ser más verdadero» ${ }^{12}$. El Padre $y$ el Hijo no superan en verdad al Padre $o$ al Hijo, etc. Repite, como se ve, el comentario del prólogo. Es decir, da la prueba de la igualdad de las divinas Personas, partiendo del concepto de verdad, atributo absoluto, idéntico a la divina esencia, que es la misma en las tres divinas Personas. Al final del capítulo vuelve a repetir este concepto: «En la esencia de la verdad, ser y ser verdadero se identifican, como se identifican el ser y ser grande» ${ }^{13}$. De nuevo, no puede olvidarse en un solo momento, al leer este libro octavo, que es introducción a la segunda parte. San Agustín quiere centrar nuestra atención sobre esa Verdad infinita, que es Dios, fuente de toda verdad, razón de la misma inteligencia. Quiere dejar esclarecido, de una vez para siempre, las relaciones que tiene el alma humana con la Verdad absoluta y fontal o fuente de toda verdad: El Dios, Verdad esencial.

El gran descubrimiento, la verdad para el hombre, es llegar a conocer la verdad de la Verdad misma que vive en la intimidad ${ }^{14}$.

Resumiendo: Sabiduría, inteligibilidad y verdad son una misma cosa para san Agustín. Así nos dice en «De libero arbitrio: «¿Acaso piensas que hay otra sabiduría distinta de la verdad, en la que se contempla y posee el sumo bien? ${ }^{15}$. Por la verdad participada, que se halla en el hombre, quiere el Santo llevarnos a la Verdad misma trinitaria.

9. «Quidquid autem intellegibile atque incommutabile est, non aliud alio verius est, qui aeque incommutabiliter aeternum est», DT 8, 1,2 PL 947.

10. «nec quod ibi magnum dicitur, aliunde magnum est, quam eo quo vere est», $i b$.

11. «magnitudo ipsa veritas est». $i b$.

12. «hoc ergo ibi est maius quod verius, ib. PL 948.

13. «in essentia veritatis, hoc est verum esse quod est esse», $i b$.

14. Cf. Adolfo MUÑoz Alonso, Intellectum valde ama. Augustinus III 1958, p. 175-176.

15. «Num aliam putas esse sapientiam nisi veritatem, in qua cernitur et tenetur summum bonum?», De lib. arb. 2,9,26 PL 32,1254; cf. P. ARIAS, Introducción, p. 56. 


\section{CAPÍtUlo $2 .^{\circ}$ LA FELICIDAD DEL HOMBRE, EL GOSO DE DiOS-VERDAD}

El capítulo segundo lo dedica san Agustín especialmente a explicar el concepto de Verdad en Dios. Resumo las ideas fundamentales.

\section{Dios es la Verdad} dad» ${ }^{16}$.

«La esencia de la verdad... es la Trinidad, Dios único, grande, veraz, ver-

En múltiples textos llama san Agustín a Dios Verdad y Luz y une estas dos palabras en un solo significado. «Ella - la Sabiduría - es la Verdad, ella es Dios... es el Verbo de Dios, es la Sabiduría de Dios, por quien fueron hechas todas las cosas» ${ }^{17}$.

No es posible eludir esta verdad, que se difunde por doquier ${ }^{18}$. Esta verdad ha sido revelada en Cristo. Él mismo es la Verdad, que «durante mucho tiempo apareció velada en promesas simbólicas» ${ }^{19}$.

Concurren en el alma, al trascenderse, la «verdad ontológica», porque descubre ser lo mismo que se conoce. Con la mirada del alma «ve en la forma que es modelo de nuestra esencia» ${ }^{20}$. La «verdad lógica», en cuanto es fundamento de todo conocimiento y verdad ulterior. La «verdad teológica», en cuanto que su último fundamento es Dios, su Creador. Es decir, los dos principios fundamentales de la interioridad agustiniana: Dios y el alma ${ }^{21}$.

La misma felicidad beatífica será «contemplar eternamente la inmutable visión de la Verdad y... alabar lo que se ama y amar lo que se alaba» ${ }^{22}$.

16. «veritatis essentia... est Trinitas Deus unus, solus, magnus, verus, verax, veritas», $D T$ $8,2,3$ PL 948.

17. «Ipsa est veritas, ipsa est Deus... Verbum Dei est, Sapientia Dei est, per quem facta sunt omnia», En in Ps 33,2,6 PL 36,310-311.

18. «totum ubique esse praesentem, sicut veritatem». Ep 118, 4,23, PL 33,443.

19. «Revelatae veritatis, quae diu promissis mysticis velabatur», Ep. 137,4,16 PL 33,523. San Agustín repite con frecuencia esta idea: En el A.T. se halla oscura y velada la verdad, que en el N.T. se aclara y se desvela; v. Sergio GonZÁLEZ, «La preocupación arriana en la predicación de San Agustín. Tratados sobre el Evangelio y $1 .^{a}$ Espístola de San Juan. Enarraciones sobre los Salmos, Sermones al Pueblo». Estudio Agustiniano, Valladolid 1989, p. 252, nota 7, donde se da un resumen sobre esta idea en San Agustín y en algunos Padres latinos y griegos.

20. «In illa igitur aeterna Veritate... formam secundum sumus, et secundum vel in nobis vel in corporibus vera et recta ratione aliquid operamur», DT 9,7,12 PL 967.

21. Sol. $1,2,7$ PL 32,872.

22. «in aeternum veritatis incommutabilem speciem contemplabitur cuius sine fine quietum opus erit... laudare quod amat, et amare qùod laudat», Ep. 140,26,63 PL 33,565-566. 
2. Dios es verdad y es luz»

«Dios es luz... una luz que el corazón intuye cuando oyes decir: Dios es verdad» ${ }^{23}$.

Cristo es la Verdad y la Luz del Padre. «El Verbo es la misma Verdad, Palabra de Dios y su Luz» ${ }^{24}$. Cristo es «la Verdad por esencia» ${ }^{25}$, el «Verbo de Dios, inconmutable verdad». "Todo cuanto fue hecho era vida en Él... vida que es luz de los hombres» ${ }^{26}$.

Esta verdad se ha de contemplar en el interior del espíritu, donde comienza el camino que lleva a la verdad. El descubrimiento de la verdad se realiza siempre en la claridad interior del corazón.

Cuando san Agustín dice que nuestra mente es iluminada por la primera verdad, se entiende en su sentido efectivo, no formal o inmediato ${ }^{27}$. La criatura racional es iluminada al contacto con el esplendor divino. Dios es nuestro sol y nosotros somos su claridad. Esta claridad orienta todo nuestro ser, toda nuestra actividad hacia Dios a través de la criatura. Ya en los diálogos ensaya san Agustín un esbozo de iluminación ${ }^{28}$. Podría seguirse en sus obras un itinerario de la mente hacia Dios por medio de las criaturas ${ }^{29}$.

Dios nos ilumina con su claridad, dándonos el inapreciable don de la inteligencia. Las verdades parciales, limitadas, son reflejos de la eterna Verdad, que es Dios. La inteligencia humana participa de esta Verdad en grado superior a los demás seres de la creación. De aquí su aspiración a llegar a un término absoluto y perfecto ${ }^{30}$.

\section{Medios para conocer la verdad}

San Agustín reflexiona sobre dos aspectos: Mediante la vía de negación y mediante la vía de eminencia. No le satisface ninguno de ellos.

23. «Deus lux est... quomodo videt cor, cum audis: Veritas est», DT 8,2,3 PL 949.

24. «Veritas et Verum in principio... unde Verbum eius et Lux eius rectissime dicitur», De ver. rel. $36,66 \mathrm{PL} \mathrm{34,151.}$

25. «qui vere veritas est», Conf. 3,6,10 PL 32, 687

26. «unum Verbum Dei est, per quod facta sunt omnia, quod est incommutabilis veritas... lux utique rationalium mentium», $D T 4,1,3$ PL 888.

27. Cf. P. ARIAS, Introducción, p. 76; cf. P. Lope Cilleruelo, La «Memoria Dei» según S. Agustín, Augustinus Magister I, 1954, p. 499.

28. Cf. Sol. 1,1,2 PL 32,870; 1,13,23 PL 32,881.

29. Cf. De ver. rel. 31,57 PL 34,61-62; Conf. 9,4,10 PL 32,768; In Io tr. 19,12 y 13 PL 35,1549-1551; De civ. Dei, 16,1 PL 41, 447.

30. Cf. P. Cilleruelo, La memoria Dei, p. 501. 


\section{Ninguna imagen puede representar la Verdad}

Porque no es nada espacial, ni corpóreo ${ }^{31}$. La imaginación reviste de figura y da forma a las cosas conocidas ${ }^{32}$. Representa cosas que se han visto y que no se han visto ${ }^{33}$. Las imaginaciones sensibles impiden al espíritu el conocimiento de sí mismo. Puede imaginarse que el espíritu es una cosa material, pero no es verdad ${ }^{34}$. Nunca una imagen sensible puede darnos un conocimiento real de la verdad, que por su misma naturaleza es espiritual. Las percepciones adquiridas "varían y se multiplican sin número hasta el infinito» ${ }^{35}$. La voluntad une y separa estas cosas percibidas y dirige a su antojo la memoria, con el fin de obligarla a pensar en las cosas que no recordamos, utilizando recuerdos y obligándolos a unir un elemento de aquí y otro de allá, para fusionarlos en una visión que se dirá falsa, porque no existe en là realidad ${ }^{36}$.

Se ha de rechazar toda imagen para llegar al conocimiento de la ver$\mathrm{dad}^{37}$, porque las imágenes de la fantasía difieren grandemente de la verdad ${ }^{38}$.

Es un tema vital en la metodología agustiniana «el evitar... que el alma, cuando cree, se finja algo irreal» ${ }^{39}$.

\section{Debe negarse también en Dios todo lo que sea mudable.}

«Nada mudable se tenga por Dios» ${ }^{40}$, porque Dios es la esencia suprema, es decir, «el que existe en sumo grado, y, por tanto, es inmutable ${ }^{41}$. Nuestra alma puede cambiar ${ }^{42}$. Dios es inmutable porque es infinito, tiene todas las。

31. v. $D T 8,2,3$ PL 948 .

32. «Facile est enim illam figuram, quam videndo cognovimus... colore perfundere», $D T$ 11,10,17 PL 997.

33. Cf. $D T$ 8,6,9 PL 954-955; v. De vera religione, 31,57 PL 32,1237.

34. Cf. DT ib. y 10,5,7 PL 977; v. V. CAPÁNAGA, La doctrina agustiniana sobre la intuición, Religión y Cultura 15(1931) p. 8-109.

35. «visiones ille cogitantium... innumerabiliter atque omnino infinite multiplicantur atque variantur», $D T$ 11,8,13 PL 994.

36. Cf. $D T 11,10,17$ PL 997-998, todo el contexto del capítulo.

37. «nulla compago iuncturae... sine ulla dubitatione respuatur: ita enim respuitur omne corporeum», DT 8,2,3 PL 948.

38. $i b$.

39. «Cavendum est, ne credens animus id quod non videt, fingat sibi quod non est», $D T$ $8,4,6$ PL 951.

40. «omne mutabile quod occurrerit non putetur Deus, DT 8,2,3 PL 948.

41. "Cum enim Deus summa essentia sit, hoc est summe sit, et ideo immutabilis sit», De civ. Dei, 12,2 PL 41,350.

42. Cf. Charles BOYER, Les voies de la connaissance de Dieu selon saint Augustin, Augustinus III, 1958, p. 305. 
perfecciones y estas perfecciones constituyen su misma esencia divina. No es posible, por tanto, cambio alguno.

Ya desde los primeros libros del tratado «De Trinitate» nos advierte san Agustín que «la esencia de Dios, razón de su existencia, nada mudable entraña, ni en su eternidad, ni en su verdad, ni en su voluntad. En Dios eterna es la verdad y eterno el amor; verdadero el amor y verdadera la eternidad; amable la eternidad y amable la verdad» ${ }^{43}$.

\section{Tampoco es válido el procedimiento o vía de eminencia para llegar a la Verdad.}

«No se obtiene aumentando ni el volumen, ni la luz... ni con los ángeles, espíritus puros» ${ }^{44}$. Ninguna cosa creada puede darnos una idea clara de esta Verdad infinita.

\section{Contemplación de la verdad}

Dios, que es la Verdad por esencia, se contempla en la interioridad, se conoce en el interior. Se obtiene únicamente por vía contemplativa, contemplando a Dios, «que es luz... una luz que el corazón intuye cuando oyes decir: Dios es verdad» ${ }^{45}$. Dios es algo íntimo, «interior est Deus» ${ }^{46}$. Esa verdad, velada mucho tiempo, aparece sólo en la interioridad.

San Agustín representa una filosofía que parte del hombre y vuelve al hombre, pero cargada ya de la presencia que el hombre refleja de lo divino. Por eso comienza con la vuelta del espíritu a sí mismo, busca la verdad, no la verdad existencial de cada uno, sino la Verdad eterna, que nos lleva en su resplandor a contemplar la presencia de Dios en el hombre. No se queda esta contemplación en el hombre, sino que se trasciende y se eleva a la Verdad misma ${ }^{47}$.

El santo Doctor nos invita constantemente a hallar la verdad en nosotros mismos. Por eso la metafísica de san Agustín empieza ya siendo una teología. Nos invita a todos al ejercicio y la prueba de la interioridad profunda, para

43. «Omnino enim Dei essentia, qua est, nihil mutabile habet, nec in aeternitate, nec in veritate, nec in voluntate: quia aeterna ibi veritas, aeterna caritas; et vera ibi est caritas, vera aeternitas et cara ibi est aeternitas, cara veritas», $D T 4$, prooemium, PL 887. 948.

44. «Nec si augeas... milies tantum, aut innumerabiliter, neque hoc est Deus», DT 8,2 PL

45. «Vide, si potes, o anima... Deus lux est... quomodo videt cor, cum audis: Veritas est, DT 8,2,3 PL 949.

46. «interior est Deus», DT 8,7,11 PL 957.

47. Cf. Pedro САВ^. La filosofía del conocimiento en san Agustín, Augustinus III, 1958, pp. 216-217. 
encontrarnos con la Verdad de cada uno y poder así trascenderse. Es decir, no busca en el hombre - lo vemos en toda la segunda parte del «De Trinitate»lo que en el hombre hay de naturaleza, sino lo que en él hay de divino. Nos invita a entrar dentro de nosotros mismos, porque allí nos encontraremos, allí hablaremos y escucharemos a Dios, porque el que «enseña está en el interior» ${ }^{48}$. La razón nos avisa desde fuera, se vale en sus razonamientos de las cosas, pero la verdad nos ilumina desde dentro.

Una y mil veces nos recuerda san Agustín la realidad de esta verdad interior ${ }^{49}$. Porque existe esta verdad dentro de nosotros mismos, podemos conocer las cosas verdaderas.

El hombre está obligado a buscar la verdad, a aceptarla como es. Ser fiel a la verdad cuando se halla, es simplemente someterse a la realidad. Ser fiel a la ley de la verdad es someterse a la ley del Ser, que es Dios mismo, Ser, Verdad y razón de todos los seres ${ }^{50}$.

Para san Agustín, nuestro pensamiento está abocado a lo necesario y absoluto, a la Verdad Absoluta, que garantiza lo absoluto y necesario. Para llegar a este Dios personal es preciso partir del conocimiento del espíritu y de sus fundamentales atributos de la inteligencia y de la voluntad. Todas las nociones de ser, de verdad y de bien se afirman en Dios de una forma absoluta, necesaria y simple. El libro octavo es un magnífico ejercicio de esta búsqueda de Dios, Verdad suma y sumo Bien.

Todo hombre constata además, que tiene «interiores regulas veritatis», eternas, necesarias, inmutables, superiores a su espíritu, que se le imponen y que no las puede cambiar. De estas verdades únicamente puede ser razón suficiente la Verdad en sí. Verdad absoluta, primera vida, primera esencia, primera sabiduría, Dios mismo. Y esta verdad nunca puede perderla el alma, incluso en la ignorancia y en el error. La ignorancia, el error o el olvido no significan que haya desaparecido la verdad, sino que se desconoce, que se opaca, pero que subsiste, y el error es tal error en cuanto hay una verdad única a la cual el error se opone. En último término, el que regla toda verdad es Dios mismo, la Verdad de toda verdad ${ }^{51}$.

Todo este proceso de encuentro con la Verdad, san Agustín nos lo quiere presentar aquí, viviente en nosotros, y quiere llevarnos al encuentro de esta Verdad, contemplándola en nuestra interioridad.

48. "qui docet intus est», En in Ps 139, 15 PL 37,1813.

49. «Intus est Deus eius, et spiritualiter intus est, et spiritualiter excelsus est», En in Ps 130, 12 PL 37,1712.

50. Cf. José Ignacio Alcorta, El conocimiento divino según san Agustín, Augustinus III, 1958, pp. 315-316.

51. Cf. Il Principio della metafisica di S. Agostino e tentativi metafisici del pensiero moderno, Michele F. Sciacca, Humanitas II, 1954, pp. 952-958. 


\section{Consecuencias}

1. ${ }^{2}$ Los seres creados, materiales y espirituales, son verdad limitada, porque la verdad es el mismo ser en cuanto dice relación al entendimiento, o el ser en cuanto el entendimiento puede conocerlo, y el ser creado es limitado. «Su grandeza no se identifica con la verdad» 52 .

2. ${ }^{2}$ El hecho de conocer «lo que Dios no es» es ya un gran paso para llegar al conocimiento de Dios ${ }^{53}$.

3. ${ }^{a}$ Todos los seres materiales y/o espirituales reunidos, en grado infinito incluso, no nos pueden dar la noción de Dios, ni aun esto sería Dios ${ }^{54}$, Verdad infinita, porque los seres son limitados y finitos y no pueden producir infinitud.

4. ${ }^{\text {a }}$ El no conocer la verdad nos llevaría a «peregrinar alejados de Dios», de error en error ${ }^{55}$.

5. ${ }^{\text {a }}$ La felicidad del hombre es el gozo de la verdad, porque es gozo de Dios, que es la Verdad ${ }^{56}$.

\section{CONOCIMIENTO MÍSTICO DE DIOS POR EL «GONCEPTO DE BONDAD»}

Ocupa este concepto todo el capítulo tercero del libro octavo. San Agustín sigue el mismo procedimiento para el concepto del Bien que para el concepto de Verdad. La bondad como la verdad son atributos absolutos que se identifican con Dios, son Dios mismo. Reconoce, por ello, la bondad de las cosas; distingue la bondad que las hace buenas; se eleva a la intuición de aquel Bien que es la misma bondad ' ${ }^{1}$. El Santo precisa los puntos siguientes sobre el concepto de bondad:

1. ${ }^{\circ}$ El hombre ama el bien y tiende hacia el bien.

$\left.2^{\circ}{ }^{\circ}\right)$ Enumeración de bienes y ascensión al Bien supremo.

52. «non eadem ibi est magnitudo quae veritas», DT 8,2,3 PL 948.

53. «Non enim parvae notitae pars est... si antequam scire possimus quid sit Deus, possumus iam scire quid non sit», $i b$.

54. ib.

55. «peregrinationis erroribus», ib. PL 949.

56. «Beata quippe vita est gaudium de veritate. Hoc est enim gaudium de te, qui veritas es Deus», Conf. 10,23,33 PL 32,793.

1. P. TRAPE, Introduzione, p. L. 
$\left.3^{\circ}\right)$ Dios, Bien sumo, medida de todos los bienes.

$\left.4 .^{\circ}\right)$ La idea del bien se halla impresa en nuestra interioridad.

$\left.5 .^{\circ}\right)$ Dios se ha de amar por sí mismo y en sí mismo.

$\left.6^{\circ}\right)$ Dios, Bien simplicísimo.

$7^{\circ}$ ) La bondad de los bienes mudables proviene del Bien inmutable.

\section{Consecuencias:}

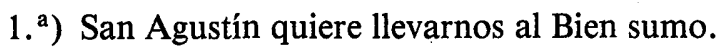

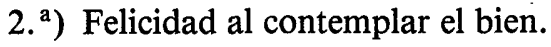

3. a) Hacia la contemplación del Dios, Uno y Trino, Verdad y Bien.

\section{CAPÍTULO $3 .^{\circ}$ LA CONTEMPLACIÓN DEL SUMO BIEN, FELICIDAD DEL ALMA}

\section{El hombre ama el bien y tiende hacia el bien ${ }^{2}$}

El hombre tiene inclinación natural hacia lo bueno, hacia el bien. Por eso nos dice san Agustín: «Ciertamente no amas sino lo bueno, pues buena es la tierra con las cresterías de sus montañas... bueno el varón justo... buenos los ángeles con su santa obediencia, etc.» ${ }^{3}$. Hay una tendencia necesaria hacia el bien aparente y, en última instancia, hacia Dios, Bien sumo, en que radica todo bien real.

La razôn metafísica de esta tendencia de la voluntad hacia el bien es porque el bien es su objeto propio y específico, y el bien, por consiguiente, es lo único que puede perfeccionarla. Implícitamente al menos, tiende a Dios mismo, Bien supremo, que es el único que puede llenar todo su deseo de bien y de felicidad.

San Agustín desea llevarnos hacia el Bien sumo y por esto hace un recuento de las bellezas y bienes de la creación, para ascender al Bien supremo, origen de todos los bienes, en el que el bien se halla en plenitud. Comienza este recuento por los bienes inferiores: la tierra y sus montañas, las llanuras y campiñas, etc. para subir hacia el hombre, en lo mejor que se halla en él: la justicia, el lenguaje, la poesía y, finalmente, subir hasta los ángeles, en su obediencia a Dios. Es el último paso para llegar a la suma Bondad.

En las Enarraciones sobre los Salmos, san Agustín nos da una definición de bondad: «Es, pues, el Ser, como el bien de bienes, es el Bien» ${ }^{4}$. Y un poco más adelante dice: Él es «el bien de todos los bienes, el bien por el cual son

2. Todo el contexto del capítulo tercero del libro octavo.

3. «Non amas nisi bonum... bona est terra... bona facies hominis... bonus vir iustus... boni angeli sancta obedientia», etc. DT 8,3,4 PL 949.

4. «Est enim est, sicut bonorum bonum, bonum est», En in Ps 134,4 PL 37,1741. 
buenas las cosas, el bien sin el cual nada es bueno, y el bien que sin las demás cosas es bueno» 5. Es más: "cada una de las criaturas tiene su bien propio: el de su integridad y el de la perfección de su naturaleza... pero el sumo Bien es tu bien ${ }^{6}$. San Agustín da la razón de aspirar al sumo Bien, «amando al bien nos hacemos mejores» ${ }^{7}$, y porque el sumo Bien es el único que «puede darnos la felicidad interior». El mismo sentido tiene aquel pasaje de las Confesiones, en que hace también un recuento de las cosas buenas, «pero Él es el mayor y sumo Bien» ${ }^{7 \mathrm{a}}$.

En el libro quinto de este mismo tratado «De Trinitate» hace una descripción maravillosa de este bien al que el hombre aspira, que es Dios: «A Dios le hemos de concebir... como un ser bueno sin cualidad, grande sin cantidad, creador sin indigencias, presente sin ubicación, que abarca, sin ceñir, todas las cosas; omnipresente sin lugar, eterno sin tiempo, inmutable y autor de todos los cambios, sin un átomo de pasividad ${ }^{8}$. Es difícil, en menos palabras, hacer una síntesis mejor de aquello que nosotros podemos conocer de Dios.

\section{Enumeración de bienes y ascensión al Bien supremo}

«¿Qué más? Bueno es esto y bueno aquello; prescinde de... esto y aquello y contempla el Bien puro, si puedes; entonces verás a Dios, Bien imparticipado, Bien de todo bien» ${ }^{9}$.

«Quid plura?... tolle hoc et illud». Parece indicar aquí san Agustín que quisiera traer en su recuento y poner ante nuestra mirada la creación entera, para que subamos con él, apreciando, sí, pero prescindiendo al mismo tiempo, de los bienes participados, hasta el Bien sumo, Bien de todo bien, «porque sólo Él es el que permanece inconmutable» ${ }^{10}$.

5. «bonum omnium bonorum, bonum a quo sunt omnia bona, bonum sine quo nihil bonum, et bonum quod sine caetaris bonum est». En in Ps 134,6 PL 37,1742.

6. «omnes creaturae habent quodam bonum suum, integritatis suae et perfectionis naturae suae... Summum bonum hoc est tuum bonum» En in Ps 102,8 PL 37,1322.

7. «bonum amando, nos meliores efficimur», En in PS 144,1 PL 37,1869.

7a. «Maius quidem et summum bonum minora fecit bona», Conf. 7,5,7 PL 32,736.

8. DT 5,1,2 PL 912.

9. «Quid plura et plura? Bonum hoc et bonum illud; tolle hoc et illud, et vide ipsum bonum, si potes: ita Deum videbis... bonum omnis boni», DT 8,3,4 PL 948.

10. «Id enim vere est quod incommutabiliter manet», Conf. 7,11,17 PL 32,742. 


\section{Dios, Bien sumo, medida de todos los bienes}

«No podemos decir, si juzgamos con verdad, que uno es mejor que otro, si no tenemos impresa en nosotros la idea del bien, según la cual declaramos buena una cosa y la preferimos a otra» ${ }^{11}$.

\section{La idea de bien se halla impresa en nuestra interioridad}

Las primeras nociones: verdad, bondad, etc., los primeros principios de sindéresis, se hallan impresos en nuestra interioridad, son objeto de la «memoria Dei» y el hombre no puede dudar de su carácter normativo. Por ejemplo «bonum est faciendum», «malum vitandum», etc. ${ }^{12}$. No podemos cambiar esta idea del bien que llevamos en nosotros ${ }^{13}$.

Estas nociones de verdad y de bien, nos son naturales, como lo son los primeros principios, que de ellas proceden ${ }^{14}$.

\section{Dios se ha de amar por sí mismo y en sí mismo}

«Dios se ha de amar, pero no como se ama este o aquel bien, sino como se ama al Bien mismo» ${ }^{15}$.

El procedimiento que sigue san Agustín en este capítulo, al hablar del Bien, es el mismo del capítulo anterior, al hablar de la Verdad. Allí, parte de las «verdades creadas», para llegar a la Verdad misma, que él llama Verdad y Luz, por la que todas las cosas son verdaderas; aquí parte de los «bienes creados», para llegar al Bien mismo, a Dios, el único que puede llamarse Bien absoluto; allí pide al lector que se libre de todas las imágenes corpóreas, que pudieran «velar la serenidad que brilló con rápido fulgor en la interioridad, al oír la palabra «Verdad»; aquí debe prescindir de «este y de aquel bien», especificativos, que limitan la bondad, para llegar al Bien mismo, a Dios, Bien de todo bien. Ambos, Verdad y Bien, se hallan en la interioridad. Es todo un proceso de interiorización, toda una pedagogía de ascensión a Dios Verdad suma y Bien supremo.

11. «Neque... diceremus aliud alio melius cum vere iudicamus, nisi esset nobis impressa notio ipsius boni, secundum quod probaremus aliquid, et aliud alii praeponeremus», $D T 8,3,4 \mathrm{PL}$ 949.

12. Cf. P. L. Cilleruelo, La Memoria Dei, según san Agustín, Augustinus Magister, I, 1954, p. 503.

13. DT 8,3,4 PL 949 .

14. Cf. F. CAYRE, La contemplation Augustinienne, p. 107.

15. «Sic amandus est Deus, non hoc et illud bonum, sed ipsum bonum», DT 8,3,4 PL 949. 


\section{Dios, Bien simplícisimo}

«Cuando, por ejemplo, oigo hablar de un alma buena, oigo dos palabras y... entiendo dos cosas: el alma y su bondad» ${ }^{16}$.

El antiguo profesor de retórica acude ahora a un ejemplo, que da luz a toda la doctrina de este capítulo. Considera en el alma dos cosas: el alma misma, el ser del alma y su bondad. El ser del alma, como tal, es siempre un bien, es siempre bueno, porque es un ser y porque ha salido de manos de Dios. Pero es más: porque es espíritu «puede decirse con toda certeza que es mejor que el cuerpo», "dicitur et verissime dicitur corpore melior». Al hablar de la bondad del alma, se refiere aquí especialmente a la bondad moral, que implica la acción de la voluntad. Para comenzar a existir nada hizo el alma, pues carecía de existencia. En cambio, «para que el alma sea buena, es necesaria la acción positiva de la voluntad». Aún más, «ni así puede decirse buena el alma, si le falta la voluntad de ser mejor» ${ }^{17}$.

Explica además san Agustín que, para que el alma logre ser mejor, necesita caminar hacia la meta ${ }^{18}$. La meta es siempre Dios, que el alma debe amar como sumo Bien.

\section{La bondad de los bienes mudables proviene del Bien inmutable}

Por tanto, «no existirían bienes mudables de no existir un Bien ínconmutable» ${ }^{19}$. Puede hablarse de bien y de bienes, de unos bienes mayores que otros, solamente en relación con el Bien inconmutable, con el que estos bienes se comparan. La bondad de los seres se pondera en relación con su menor o mayor proximidad, parecido y participación del Bien sumo. Este Bien «hace a las cosas buenas» ${ }^{20}$. El Bien inconmutable, «incommutabile bonum», es también la Verdad y el Bien puro, «haec est veritas, et simplex bonum» ${ }^{21}$.

16. «animus bonus... duo verba... duo quaedam intellego: aliud quod animus est, aliud quo bonus», etc. $D T i b$.

17. «sed ideo nondum dicitur bonus animus, quoniam restat ei actio voluntatis, qua sit praestantior", $D T i b$. PL 950. DT ib.

18. «bonus animus, nisi ad aliquid convertat quod ipse non est, non potest hoc assequi», 950.

19. "Quapropter nulla essent mutabilia bona, nisi incommutabile bonum», $D T 8,3,5$ PL

20. «bonum ipsum unde bona sunt», $i b$.

21. «incommutabile bonum... Haec est veritas, et simplex bonum», $i b$. 


\section{1. ${ }^{a}$ consecuencia}

Una vez más, san Agustín quiere llevarnos a fijar la mirada en el Bien sumo: «Es vergonzoso amar las cosas buenas, apegarse a ellas y no amar el Bien que las hace buenas» ${ }^{22}$.

\section{2. ${ }^{a}$ consecuencia}

Insiste el santo Doctor en llevar a sus lectores, por la conversión, hasta el Bien y la Verdad. La contemplación y el amor del Bien y la Verdad, que hará al instante feliz al alma ${ }^{23}$, ha de realizarse en la propia interioridad, porque en el interior brillan, en todo su esplendor, los conceptos de Bien y de Verdad. Por esto termina este capítulo con estas significativas palabras, que iluminan todo su contenido: Dicho Bien no se encuentra lejos de cada uno de nosotros: «En él vivimos, nos movemos y existimos» (Hch 17,27,28).

\section{3. ${ }^{a}$ consecuencia}

Llevar a los lectores hacia la contemplación del Bien y de la Verdad, de Dios mismo, Uno y Trino, es el empeño de san Agustín en todo el tratado «De Trinitate» y aquí nos propone el modelo sintetizado en el Bien.

\section{CONOCIMIENTO MÍSTICO DE DIOS POR EL «CONCEPTO DE JUSTICIA»}

San Agustín reflexiona sobre el concepto de justicia en los capítulos sexto y noveno, del libro octavo del tratado «De Trinitate». En el capítulo sexto desarrolla fundamentalmente el concepto. El capítulo noveno se refiere a Dios mismo, «ideal inconmutable» de toda justicia, conforme al cual debe vivir el hombre su propia justicia.

San Agustín relaciona especialmente la justicia con la caridad.

\section{Puntos fundamentales:}

$10^{\circ}$ - La justicia radica en el alma

$2 .^{\circ}$ - Definición de justicia

$3 .^{\circ}$ - Ideal de justicia

22. «Pudeat autem, cum alia non amentur nisi quia bona sunt, eis inhaerendo non amare bonum-ipsum unde bona sunt», $i b$.

23. «Et si amore inhaeretis, continuo beatificaberis», $i b$. 


\section{Consecuencias:}

1. ${ }^{a}$ El alma, principio de vida.

2. ${ }^{a}$ Semejanza solamente parcial con el modelo.

3. ${ }^{\text {a }}$ Amar al hombre para que sea justo.

4. Amar en sí mismo la justicia

5. ${ }^{\text {a }}$ Amar al hombre por su conformidad con el modelo

6. ${ }^{\mathrm{a}}$ Orientación en la práctica del amor.

\section{CAPÍTULOS $6 .^{\circ}$ y $9 .^{\circ}$ LA JUSTICIA, UNA FORMA DE AMOR Y DE CARIDAD}

\section{1.- La justicia radica en el alma}

— «Amamos su alma justa» (alma del Apóstol, ejemplo explicativo) ${ }^{1}$.

- «La razón de amar al Apóstol es la santidad de su alma» ${ }^{2}$.

- «En el hombre el alma sola es justa. Cuando se dice que el hombre es justo, se entiende según el alma, no según el cuerpo» ${ }^{3}$.

\section{Concepto o definición de justicia}

- «Es la justicia una cierta belleza del alma, que hace a los hombres hermosos, aunque sus cuerpos sean deformes y enfermizos» ${ }^{4}$.

- «Justa es el alma que regla su vida y sus costumbres conforme a los dictados de la ciencia y de la razón, y da a cada uno lo suyo» ${ }^{5}$.

«Dar a cada uno lo suyo». Indicaría en esta definición el «sentido jurídico» de la justicia ${ }^{6}$. Es decir, la justicia, así entendida, exalta el valor de cada persona, que tiene derechos inalienables, que todos deben respetar. Pero san Agustín, filósofo cristiano, no se conforma con esta definición. La virtud, toda virtud verdadera es, para él, «orden del amór»; "ordo amoris» ${ }^{7}$. La defini-

1. «amamus enim animum iustum», DT 8.6,9 PL 953.

2. «non alia causa diligere, nisi quod sit iustus animus», ib. PL 954.

3. «Iustus autem in homine non est, nisi animus: et cum homo iustus dicitur, ex animo dicitur», $i b$.

4. «Est enim quaedam pulchritudo animi iustitia, qua pulchri sunt homines, plerique etiam qui corpore distorti atque deformes sunt», $i b$.

5. «Iustus est animus qui scientia atque ratione in vita ac moribus sua cuique distribuit», DT 8,6,9 PL 955; cf. De civ. Dei 19, 21 PL 41,648s; v. S. Ambrosio, De officiis, 1,24,115 PL 16,57 .

6. Cf. Fr. Joseph Thonnard, Justice de Dieu et justice humaine selon saint Augustin, Augustinus XII,388.

7. «ordo amoris», De civ. Dei 15,22 PL 41,467; v. Lope CILlERuElo, Teología Espiritual I. Ordo Amoris (Separata). Estudio Agustiniano, Valladolid, 1976. 
ción propia de virtud «no es otra que un perfecto amor a Dios» ${ }^{8}$. Por este amor «no sirve más que a Dios»... y ordena «todo lo inferior al hombre»?. Comprende esta definición, típicamente agustiniana, a todas las personas susceptibles de tener derechos que se deben respetar, incluyendo, evidentemente, las tres divinas Personas, que son los derechos en sumo grado, infinitamente más dignos de respeto que los derechos de cualquier persona ${ }^{10}$.

La justicia en Dios, como la Verdad y el Bien, se identifican con su misma esencia ${ }^{11}$. La justicia cristiana es una forma de amor y de caridad. Por ello la justicia, así comprendida, rompe todos los moldes antiguos de las virtudes morales y cardinales de los paganos. La justicia es la santidad y realiza toda la perfección.

San Agustín identifica la justicia con la caridad. Nos lo dice claramente: «La caridad incoada es la justicia incoada, la caridad avanzada es la justicia avanzada; la caridad perfecta es la justicia perfecta» ${ }^{12}$. Pero hay más, el Santo considera la justicia como la principal de las virtudes morales y, lógicamente, la relaciona especialmente con la caridad ${ }^{13}$. Este concepto lo tiene ya san Agustín en sus primeras obras.

La plenitud de esta justicia se realizará totalmente en el cielo ${ }^{14}$, «cuando la caridad será plena, porque la plenitud de la ley es la caridad» (Rom 13,10). Los que viven aun en la fe llegarán a la justicia perfecta únicamente cuando la fe se transforme en visión eterna ${ }^{15}$. Esto incluye la gracia de Cristo, sin la cual ninguna verdadera santidad, ninguna justicia, en sentido religioso, es posible ${ }^{16}$.

«La afirmación central de la teología agustiniana es: que la justicia del hombre no puede provenir más que de Dios Padre, que actúa por Jesucristo, su Hijo único, en la gracia del Espíritu Santo. Agustín presenta esta justicia en el cuadro general de su teología de la historia» ${ }^{17}$.

8. «nihil omnino esse virtutem affirmaverim, nisi summum amorem Dei», De mor. Eccl. cath. 1,15,25,PL 32,1322.

9. «iustitiam, amorem Deo tantum servientem, et ob hoc bene imperantem ceteris, quae homini subiecta sunt», $i b$.

10. Cf. Thonnard, o.c., p. 389.

11. «Hoc (Deus) est quod habet... habendo utique vitam, et eadem vita est», De civ. Dei 11,10,1 PL 41,325.

12. «Charitas... inchoata, inchoata iustitia est... charitas magna, magna iustitia est», De nat. et grat. 70,84 PL 44,290.

13. Cf. Contra duas ep. Pelag. 3,7,21 PL 44,603-604.

14. «Tunc ergo erit plena iustitia, quando plena sanitas; tunc plena sanitas, quando plena caritas... plena caritas quando videbimus eum sicuti est», De perf. iust. hom., 3,8, PL 44,295.

15. «Quocirca post resurrectionem hominis, futuram negare iustitiae plenitudinem... dementiae singularis est», Contra duas ep. Pelag., 3,7, 23 PL 44,606.

16. Cf. ThonnARD, .c., p. 396.

17. Cf. Basil Studer, La Christ. nostre justice, selon saint Augustin, trad. M. Bueno y J. Oroz, Augustinus XXVI, 103-104. 


\section{Ideal de justicia}

-Radica en el interior: «En nosotros conocemos lo que es justo... dentro de mí mismo»" ${ }^{18}$.

— «Se llega a ser justo adhiriendo al ideal» ${ }^{19}$.

— «Esta adhesión se hace por amor: amando al hombre... en el modelo donde se ve lo que es un alma justa», donde se puede apreciar la justicia ${ }^{20}$, porque sería absurdo amar la justicia en el hombre y no amar la Justicia misma que lo hace justo ${ }^{21}$.

-Es «en Dios donde contemplamos el ideal inconmutable de toda justicia, conforme al cual juzgamos cómo deben vivir los mortales» ${ }^{22}$.

-El modelo de justicia es Dios, justicia inmutable, que hace justo al hombre. Es un pasaje paralelo al Bien inconmutable, que hace buenas todas las cosas ${ }^{23}$.

- «El ideal de justicia lo vemos en lo íntimo de nosotroS mismos, mejor, por encima de nosotros» ${ }^{24}$, «en la misma verdad» ${ }^{25}$.

Llama la atención la insistencia con que san Agustín presenta la interioridad como el centro donde se han de contemplar la Verdad, el Bien, la Justicia. El ideal de justicia, por tanto, radica en el interior, se percibe en el interior, lo conocemos en nosotros mismos. El santo Doctor quiere hacernos ver que el hombre, por su verdad, bondad, justicia y amor limitados, participa de la Verdad suma, del Bien, de la Justicia y del Amor esencial que es Dios mismo. No pueden eludirse estas primeras nociones elementales, que se hallan impresas en el alma, que se pueden intuir fácilmente, que son objeto de la «memoria Dei» ${ }^{26}$.

18. «In nobis igitur novimus quid sit iustus... et si interrogem alium quid sit iustus, apud se ipsum quaerit quid respondeat», DT 8,6,9 PL 954 .

19. «inhaerendo eidem ipsi formae quam intuentur, ut inde formentur et sint iusti animi», ib. PL 955.

20. «Unde inhaeretur illi formae, nisi amando?... diligimus iustum... et non diligimus ipsam forman ubi videmus quid sit iustus animus, $i b$. PL 955-956.

21. $i b$.

22. «in Deo conspicimus incommutabilem formam iustitiae, secundum quam vivere oportere iudicamus», $D T 8,9,13$ PL 960.

23. $D T$ 8,3,5 PL 950; «Cur ergo ipsam formam ubi videmus quid sit iustus animus... ut et nos iusti esse possimus, $D T 8,6,9$ PL 956.

24. «intus apud nos, vel potius supra nos».

25. «in ipsa veritate conspicimus, DT ib. PL 959.

26. Cf. L. Cilleruelo, La Memoria Dei según san Agustín, Augustinus Magister I, 1954, pp. 503-404; v. Aimé SolignAc, Le livre $X$ des Confessions, p. 24 y nota 8. Lectio Augustini. Settimana Agostiniana Pavese. Ed. Eugustinus, Palermo, 1987. El autor sigue a G. Madec, Pour Ou contre la Memoria Dei, REAug 11,1965, pp. 89-92. 
Como imagen de Dios, el hombre no puede eludir la idea de justicia, que ve reflejada siempre en sí mismo. Esta participación es el lazo de unión del hombre con Dios ${ }^{27}$. En este ideal percibe el hombre cómo debe orientar toda su vida, para imitar la justicia y la santidad de Dios.

Dios mismo, ideal de justicia, «vive inconmutablemente» y nuestra mayor o menor justicia depende de la mayor o menor participación de la justicia de Dios. En la carta 120 toma san Agustín la justicia en sentido no meramente jurídico, sino religioso: santidad de vida, y la aplica a Dios esencialmente y al hombre como participada de Dios ${ }^{28}$.

Aun en las especulaciones psicológicas más sublimes, se funda siempre en la economía de la Encarnación, como puede verse en los libros cuarto y décimotercero de este mismo tratado «De Trinitate». Cristo es para san Agustín «el justo y el que justifica; nosotros somos justificados por su gracia» ${ }^{29}$. Jesucristo es para nosotros el «ejemplo exterior y el sacramento de nuestra justificación interior. Cristo mismo es la justicia de Dios» ${ }^{30}$.

Existe además, para san Agustín, una solidaridad de Cristo con nosotros. Cristo es «Cabeza de su cuerpo y el único Mediador entre Dios y los hombres, es el hombre Cristo Jesús... Él se dignó morir por nosotros para hacernos miembros suyos. Algunas veces habla en persona de sus miembros, otras en su propia persona, como Cabeza nuestra» ${ }^{31}$.

En la Enarración sobre el salmo 57 establece una ecuación entre el justo y el fiel ${ }^{32}$, y entre el injusto e infiel. $Y$ en el «Comentario sobre el Evangelio de san Juan» nos dice «que el justo vive de la fe y el injusto está muerto» ${ }^{33}$.

La sangre de Cristo fue nuestro precio y por ella ahora somos herederos de la gracia de Dios ${ }^{34}$. Por sí solo el hombre nunca podría alcanzar esta justificación ${ }^{35}$.

27. ib. p. 502.

28. «et tanto magis minusve iusti sumus, quanto magis illi magis minusve cohaeremus», Ep. 120, 4,19 PL 33,461.

29. «Christus et iustus est, et iustificans; nos autem iustificati gratis per gratiam ipsius», Ep. 185. 40 PL 33,810.

30. «Hanc Dei iustitiam... quod Christus est», De civ. Dei, 21,24,5 PL 41,740; Cf. B. STUDER, o.c., p. 275.

31. «Jesum Christum caput esse corporis sui, illum unum mediatorem esse Dei et hominum, hominem Jesum... qui... dignatus est mori pro nobis membra sua nos fecit. Aliquando itaque ex persona membrorum suorum loquitur, aliquando ex persona sua, tamquam capitis nostri», En in Ps 142,3 PL 37,1845-1846; cf. Tr., in Jn ev. 53,10: PL 35,1778.

32. En in Ps 57,21 PL 36,691.

33. «Iustus autem ex fide vivit» (Rom 1,17). Infideles quid? mortui sunt», In Jn ev. tr. 22,6 PL 35,1577.

34. «ad Christi gratiam pertinentes», $D T$ 13,15,19 PL 1029.

35. Cf. $D T 14,15,21$ PL 1051 s. 


\section{Consecuencias:}

$1 .^{\text {a }}$ - La vida y el movimiento del cuerpo vienen por el alma, «principio que es vida y es alma», es decir, principio que vitaliza el cuerpo ${ }^{36}$.

2. a - No se llega a una semejanza total con el modelo. «La única semejanza total con el modelo es el modelo mismo; propiamente nada se le asemeja, porque sólo Él es tal cual es» ${ }^{37}$. Repite aquí también el argumento del capítulo tercero: allí el Bien, aquí la Justicia.

3. ${ }^{2}$ - Orientación del amor en el hombre: «Al hombre se ha de amar o porque es justo o para que sea justo" ${ }^{38}$.

4. ${ }^{\mathrm{a}}$ - Orientación del amor a sí mismo: «Con igual amor se ha de amar al hombre que a sí mismo; es decir, o porque ya es justo o para hacerse justo» ${ }^{39}$.

5. - Amamos al hombre justo porque se ha conformado en su vida con el modelo de justicia ${ }^{40}$. Y «si primariamente no amáramos al modelo... no amaríamos al que se ha conformado a este ideal de su vida mientras vivió en carne mortal»" ${ }^{4}$.

6. ${ }^{\mathrm{a}}$ - Al final del capítulo octavo, resume san Agustín cómo ha de ser en la práctica nuestro amor: «A Dios hemos de amarle incomparablemente más que a nosotros mismos: al hermano, como nos amamos a nosotros; y cuanto más amemos a Dios, más nos amamos a nosotros mismos. Con un mismo amor de caridad amamos a Dios y al prójimo por Dios» ${ }^{42}$.

El capítulo noveno, finalmente, es una consecuencia de la doctrina esquématizada en este apartado. En efecto, el amor a la justicia increada nos enciende y nos lleva al amor del prójimo que es, en resumen, el contexto de todo el capítulo sexto.

36. «quod est vita et anima», DT 8,6,9 PL 954 .

37. «sola ipsa talis est, qualis est» $i b$. PL 956.

38. "Qui ergo amat homines, aut quia iusti sunt, aut ut iusti sint, amare debet», $i b$.

39. «Et semetipsum amare debet... quia iustus est, aut ut iustus sit», $i b$.

40. $i b$.

41. «Nisi hanc formam, quam semper stabilem atque incommutabilem cernimus, praecipue diligeremus, non ideo diligeremus illum, quia eius vitam, cum in carne viveret, huic formae coaptatam et congruentem fuisse, fide retinemus», $D T$ 8,9,13 PL 959.

42. «incomparabiliter plus quam nobis Deo, fratri autem quantum nobis ipsis; nos autem ipsos tanto magis diligimus, quanto magis diligimus Deum. Ex una igitur eademque caritate Deum proximumque diligimus: sed Deum propter Deum, nos autem et proximum proter Deum», DT 8,8,12 PL 959. 


\section{CONOCIMIENTO MÍSTICO DE DIOS POR EL «CONCEPTO DE CARIDAD»}

El concepto de caridad es el más importante y el más complejo del libro octavo del tratado «De Trinitate». Le dedica san Agustín los capítulos cuarto -introductorio-, quinto, séptimo, octavo y décimo. Por ello creo necesario hacer un esquema previo de estos capítulos al tiempo para mayor claridad.

Ideas fundamentales de estos capitulos:

CApítulo $4 .^{\circ}$

1. ${ }^{\text {a }}$ Orientación del concepto de amor.

2. ${ }^{\text {a }}$ Necesidad de un conocimiento previo.

3. ${ }^{\text {a }}$ Conocimiento por medio de la fe.

4. ${ }^{a}$ Definición del amor.

Consecuencia: Necesidad de amar al hermano para amar a Dios.

\section{Capítulo $50^{\circ}$}

1. ${ }^{\text {) }}$ La humildad, centro de la cristología agustiniana.

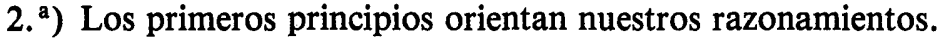

3. $\left.{ }^{a}\right)$ Únicamente salva la fe.

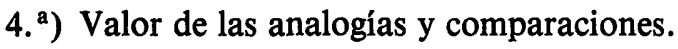

Idea secundaria: Fe de san Agustín en la maternidad divina de María. Consecuencia: Única seguridad en la fe.

\section{CAPITULO 7.}

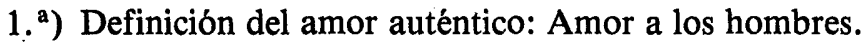

Consecuencias:

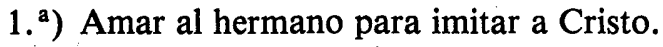

2. ${ }^{\text {a) }}$ Con una sola palabra expresa la Escritura los dos amores.

2. $\left.{ }^{a}\right)$ Idea fundamental: A Dios se le halla en el interior.

Consecuencia: La humildad, camino seguro para hallar a Dios.

\section{CAPítulo 8. ${ }^{\circ}$}

1. ${ }^{\text {a }) ~ E l ~ a m o r ~ a l ~ h e r m a n o, ~ s i g n o ~ d e l ~ a m o r ~ a ~ D i o s . ~}$

2. ${ }^{\text {a }) ~ E l ~ a m o r, ~ v i ́ n c u l o ~ e n t r e ~ l o s ~ h e r m a n o s ~ y ~ c o n ~ D i o s . ~}$

3. ${ }^{\text {) }}$ La Trinidad se halla siempre en el amor verdadero.

4. ${ }^{\text {a) }}$ El amor fraterno es don de Dios y es Dios mismo.

5. ${ }^{\text {) }}$ Orden que ha de tener nuestro amor. 


\section{Consecuencias:}

$1^{a}$ ) La perfección radica en el amor al hermano.

2. $\left.{ }^{a}\right)$ En el amor al hermano se cumplen los dos preceptos.

3. ${ }^{\text {a }) ~ E l ~ a m o r ~ a ~ D i o s ~ d a ~ a u t e n t i c i d a d ~ a ~ n u e s t r o ~ a m o r . ~}$

\section{CAPItUlo $100^{\circ}$}

1. $\left.{ }^{a}\right)$ La caridad es el amor del bien.

2. ${ }^{\text {) }}$ El amor supone un amante y un objeto amado que se ama.

3. ${ }^{\text {a) }}$ El amor es vida que une dos vidas.

\section{Consecuencia final:}

Descubierta la primera imagen trinitaria en el amante, el amado y el amor, san Agustín descansa y nos invita a descansar para emprender, con este ensayo, la subida hacia la Trinidad.

\section{CAPÍtUlo $4 .^{\circ}$ LA FE, PREÁMBULO DEL AMOR}

El capítulo cuarto del libro octavo presenta algunos conceptos previos para orientar debidamente el auténtico amor. La fe es la luz que ilumina el amor en su misma base. El santo Doctor subraya estos puntos fundamentales:

\section{Orientación del concepto de amor}

La fe en los escritos de san Agustín no puede comprenderse en el marco de una definición. La fe afecta al alma y reside en sus dos facultades: entendimiento y voluntad, que corresponden a las dos principales actividades del hombre, el conocimiento y el amor.

Es la fe viva, la vivencia de la fe, la que nos conduce a la inmortalidad y a la vida eterna.

La fe tiene cierta prioridad lógica sobre la esperanza, la caridad, la justicia y sobre las virtudes morales. Cualquier otra cosa esencial a la vida interior del hombre, cualquier otro elemento necesario a la unión con Dios, no puede subsistir sin la fe. El conocer a Dios es anterior a la justicia, a la esperanza y a la caridad. Por esto inserta san Agustín el capítulo cuarto sobre la fe, antes de hablar de la justicia y del amor, que ocuparán el resto del libro octavo. Por eso nos dice al principio del capítulo: «Es necesario permanecer cabe Él y adherirse a Él por amor, si anhelamos gozar de su presencia» '. Sólo estas pala-

1. «Sed dilectione standum est ad illud et inhaerendum illi, ut praesente perfruamur a quo sumus», $D T$ 8,4,6 PL 951; «nisi nunc iam diligamus, nunquam videbimus», $i b$. 
bras dan una orientación a todo el capítulo y, a mi parecer, a todo el concepto de amor, el más amplio del libro octavo. Fundamento así esta afirmación:

-El amor impulsa a san Agustín a escribir sobre la Trinidad: «Confieso que estas cosas tienen holgada mansión en mi entendimiento, pues me inflamo de amor de indagar la verdad ${ }^{2}$. Y termina el tratado diciendo: «Te he buscado fija la mirada en esta regla de fe... y anhelé ver con mi inteligencia lo que creía con mi fe» ${ }^{3}$.

-Sólo el amor a Dios, Bien absoluto, que anhela siempre el alma, puede llamarse bueno y dar la felicidad ${ }^{4}$.

\section{Necesidad de un conocimiento previo}

Se ama lo que se conoce de alguna manera, «porque nadie puede amar una cosa ignorada por completo» ${ }^{5}$. Por ello san Agustín nos dice, como preámbulo del amor, cómo ha de comenzarse y qué condiciones debe tener nuestro amor.

Para el Obispo de Hipona, conocer a Dios es «contemplarle, percibirle con toda firmeza. No es cuerpo para que se le busque con los ojos de la carne» ${ }^{6}$.

Plantea a continuación san Agustín una argumentación progresiva, para hacernos ver cómo debe ser el conocimiento de Dios, que ha de terminar en la fe verdadera, no fingida. Había terminado el capítulo tercero con estas palabras: «Este Bien no se encuentra lejos de cada uno de nosotros: En Él vivimos, nos movemos y existimos» (Hech $17,27-28)^{7}$. Sentada esta premisa, continúa con la argumentación progresiva:

- Es necesario permanecer cabe Él y adherirse a Él por amor».

- «Mas ¿quién ama lo que ignora?».

-Y, ¿qué es conocer a Dios, sino contemplarle y percibirle con la mente con toda firmeza»?

Aquí podría terminar la argumentación, porque da la prueba por la que no se puede percibir a Dios: «No es Dios cuerpo para que se le busque con los

2. DT 1,5,8 PL 825 .

3. «et desideravi intellectu videre quod credidi», DT 15,28,51 PL 1098.

4. DT 8,3,4 PL 949-950.

5. «Rem prorsus ignotam amare omnino nullus potest», DT 10,1,1 PL 971 .

6. «Sed... nemo diligit Deum antequam sciat. Et quid est Deum scire, nisi eum mente conspicere, firmeque percipere», DT 8,4,6 PL 951.

7. «Hoc ergo bonum (Deus) non longe positum est ab unuquoque nostrum»: In illo vivimus etc. $D T$ 8,3,5 PL 950s. 
ojos de la carne». Da la prueba para no fatigar la mente con esta argumentación demasiado larga, y continúa:

- «Pero antes que podamos contemplar y conocer a Dios... es menester amarle por la fe, porque sin la fe el corazón no puede ser purificado ni hacerse idóneo y apto para la visión».

- «Se ama lo que se ignora, pero se cree» ${ }^{8}$, se ama si existe la fe.

Termina aquí su argumentación. Si la fe está impregnada de amor, es la fe no fingida, que nos dice a continuación: No conocemos a la Trinidad «aplicando la regla de analogía, según un conocimiento genérico o específico» ${ }^{9}$, sino por medio de la fe, que ha de ser siempre el punto de partida para toda investigación sobre la Trinidad especialmente, y sobre cualquier otro misterio de la fe.

\section{Conocimiento por medio de la fe}

Insiste san Agustín en este capítulo en la autenticidad y veracidad de nuestra fe: «Hemos de evitar que el alma, cuando cree lo que no ve, se finja algo irreal y ame lo que es falso» ${ }^{10}$. Para que la fe no sea fingida debe «brotar de un corazón puro, de una conciencia recta». La fe verdadera va siempre unida a la esperanza y a la caridad.

La imaginación es un impedimiento para la fe, porque es una necesidad para nuestro espíritu el imaginar, y la imaginación puede desfigurarla. Concebimos, en efecto, todas las cosas realizadas en un espacio y en un tiempo determinado.

La fe en la Trinidad, hacia la que quiere orientar san Agustín a sus lectores, ha de alejarse de toda imaginación, de toda imagen, que sería falsa. Dios es espíritu puro, es espiritual. Por eso dice más adelante: «Nuestra fe no se ocupa del óvalo facial y de los contornos somáticos de los personajes, sino de la vida que llevaron por la gracia de Dios» ". Es más, en la misma fe que tene-

8. «Dilectione standum est ad illud et inhaerendum illi;

- «Sed quis diligit quod ignorat»;

- «Et quid est Deum scire, nisi eum mente conspicere, firmeque percipere»;

-Sed priusquam valeamus conspicere atque percipere... quod mundioribus licet... nisi per fidem diligatur, non poterit mundari, quo ad eum videnum sit aptum et idoneum.

- «Amatur ergo et qui ignoratur; sed tamen creditur», DT 8,4,6 PL 951.

9. Cf. $D T 8,5,8$ PL 952.

10. «Cavendum est, ne credens animus id quod non videt, fingat sibi aliquid quod non est, et speret diligatque quod falsum est», DT 8,4,6 PL 951.

11. «Neque ibi occupatur fides nostra, qua facie corporis fuerint illi homines; sed tantum quia per Dei gratiam ita vixerunt», DT 8,4,7 PL 951 .

Cf. Umberto Occhialini, La Speranza della Chiesa Pellegrina, Assisi 1955, pp. 144-153, donde hace un estudio sobre las relaciones entre la esperanza, la fe y la caridad. 
mos en Jesucristo, «no es lo que salva la ficción del alma... sino nuestro pensamiento sobre la naturaleza específica del hombre ${ }^{12}$. No es la imagen la que salva, sino la fe. La imagen puede ser falsa, la fe siempre es verdadera.

San Agustín precisa tres expresiones:

- «Credere alicui», que expresa la persona cuya palabra se acepta como verdadera. Y así creemos «a» Dios. Éste es el primer precepto y el principio de la religión» ${ }^{13}$.

- «Credere aliquem», que expresa las personas y las cosas que forman el objeto de la fe, es decir, aceptar el cuerpo de verdades reveladas ${ }^{14}$. Ésta es, v.gr. la verdad de la Trinidad inmutable.

- «Credere in aliquem», es decir, una fe llena de amor, que lleva a Él e incorpora al creyente a sus miembros. Ésta es la fe que justifica.

Hay una gran diferencia entre creer en Cristo como verdad objetiva y creer en Cristo como Salvación. «La existencia de Cristo también la creyeron los demonios y... no creyeron en Cristo. Cree, pues, en Cristo quien espera en Cristo y quien le ama, quien viene a Él, se une a Él... lo cual sólo es posible si la fe va acompañada de la caridad ${ }^{15}$.

Explica también san Agustín cómo es posible el conocer, si efectivamente, nuestra fe se acomoda a la realidad: «Llevamos como grabada en el alma la noción de la naturaleza humana — pone un ejemplo explicativo- y según esța noticia reconocemos al momento al hombre» ${ }^{16}$.

El conocimiento intelectual, al que quiere orientarnos san Agustín, señala precisamente la distancia fundamental del hombre con los demás seres de la creación. La inteligencia se orienta por las ideas inmutables y juzga en conformidad con ellas ${ }^{17}$. Los principios elementales, como la noticia de la naturaleza humana, los conceptos de verdad, bondad, espiritualidad, justicia, etc. se hallan grabados en el fondo del alma y, por medio de ellos, podemos juzgar la veracidad o falsedad de un concepto. A estos principios debe adecuarse nuestro conocimiento para que sea objetivo.

En resumen: la fe debe purificar los corazones y prepararlos para la visión. «La visión es premio de la fe verdadera» ${ }^{18}$. La fe, para san Agustín, es el

12. DT 8,4,7 PL 951-952.

13. «credere alicui», Sermo 38,5 PL 38,237 .

14. «credere aliquem», De civ. Dei 4,20 PL 41,127; credimus immutabilem Trinitatem, De ag. Christ. 17,19 PL 40,300.

15. «credere in aliquem», Sermo 144,2 PL 38,788 .

16. DT 8,4,7 PL 952 .

17. Cf. SCIACCA, Introduzione, p. 84.

18. «Contemplatio quippe merces est fidei, cui mercedi per fidem corda mundantur», $D T$ 1,8,17 PL 832 . 
primer paso para el conocimiento del orden sobrenatural. Aparentemente sería más natural empezar por la razón y terminar por la fe; pero para san Agustín es camino más seguro «el creer para conocer». Es imposible la misma vida humana sin postulados que se acepten y que sirvan como puntos de partida del pensamiento de la vida misma. "Creer, nos dice, es pensar asintiendo» ${ }^{19}$. Es necesario que todo lo que se cree se crea después de haberlo pensado.

El fondo del problema incluye las relaciones entre la fe y la razón. Es éste, a mi parecer, un motivo fundamental por el que inserta este capítulo sobre la fe, como orientación pedagógica de nuestra fe en el misterio trinitario. San Agustín confirma la distinción entre la fe y la razón y excluye la separación entre ellas. Fe y razón han de caminar unidas en esta investigación psicológica sobre el misterio trinitario.

En resumen: el Santo Doctor quiere conducir al lector por el camino de la búsqueda y le indica la actitud que debe tomar. Precede la fe y sigue el entendimiento. En el sistema agustiniano, el entendimiento, iluminado por la gracia, sale al encuentro de la fe ${ }^{20}$.

\section{Definición del amor}

Como orientación de cómo debe ser nuestro amor, san Agustín aclara en qué consiste el verdadero amor: «Es vivir justamente adheridos a la verdad y despreciar todo lo perecedero por amor a los hombres» ${ }^{21}$.

\section{Consecuencia fundamental:}

Fiel seguidor del discípulo amado nos dice: «Quien no ama a su hermano no está en Dios, porque Dios es amor» $(1 \mathrm{Jn} 1,4,8){ }^{22}$.

\section{CAPÍTUlo $5 .^{\circ}$ POR LA HUMILDAD Y LA FE AL AMOR DE LA TRINIDAD}

Continúa el capítulo quinto, de un modo más acentuado, la introducción al amor. Insiste san Agustín en centrar los conceptos hasta llegar al capítulo décimo, que es el despliegue final del tema sobre el amor, introductorio a la segunda parte del gran tratado. 44,963

19. «credere nihil aliud est, quam cum assensione cogitare», De praed. sanct. $2,5 \mathrm{PL}$

20. «praecedit fides, sequitur intellectus», Sermo 118,1 PL 38,672.

21. «Haec est... vera dilectio, ut inhaerentes veritati iuste vivamus». DT 8,710 PL 956.

22. «Qui... non diligit fratrem, non est in dilectione... quia Deus dilectio est». DT 8,8,12 PL 958. 
En su especulación y búsqueda, el santo Doctor repite intencionadamente muchos conceptos, siguiendo el principio pedagógico del prólogo, ya mencionado en este estudio: «Queden sentadas estas verdades, y cuanto más en nuestro estudio las repitamos, más familiar nos será su conocimiento». Esto nos explica las varias definiciones que da, por ejemplo, de la bondad, de la interioridad y del amor a lo largo del libro octavo.

\section{Puntos fundamentales:}

\section{La humildad, centro de la cristología agustiniana}

La humildad es la prueba por excelencia del amor de «Dios hecho hombre por nosotros, para darnos ejemplo de humildad». Es la «razón de la Encarnación y medicina eficaz de nuestra soberbia» ${ }^{23}$. Quiere hacernos ver san Agustín la necesidad de la aceptación humilde cuando se habla del misterio. El contexto de todo el capítulo - continúa implícitamente el tema del capítulo anterior sobre la fe- se refiere a la posibilidad de amar a la Trinidad sin conocerla. San Agustín aduce ejemplos explicativos, antes de dar la respuesta.

\section{Nuestros razonamientos se orientan siempre por los primeros principios,} «ideas injertadas por el Hacedor en nuestra naturaleza, o adquiridas mediante la experiencia» ${ }^{24}$.

Reflexiona e insiste san Agustín en la realidad de estos primeros principios en nuestro interior. Lo repite en los cuatro conceptos fundamentales de este tema: verdad, bondad, justicia y amor.

\section{La fe es la única que salva}

Por ella creemos y conocemos, y «amamos a la Trinidad, que es Bios» ${ }^{25}$.

Aduce san Agustín varios ejemplos e intenta con ellos demostrar cómo la fe es la única que salva. La imaginación nunca o muy contadas veces conoce la realidad de las cosas tal cual es, hasta el punto de que nosotros mismos nos sorprendemos cuando, al conocer realmente una cosa, es como previamente la habíamos imaginado. La fe, en cambio, no falla jamás.

23. «credimus pro nobis Deum hominem factum, ad humilitatis exemplum, et ad demonstrandum erga nos dilectionem», DT 8,5,7 PL 952.

24. «Deo credimus et secundum species et genera rerum vel natura insita vel experientia collecta, de factis huiuscemodi cogitamus» DT 8,5,7 PL 953.

25. «Hoc ergo diligimus in Trinitate, quod Deus est», DT 8,5,8 PL 953. 
En el «Comentario sobre el Evangelio de san Juan» nos habla de una fe llena de amor, una fe que nos lleva a Cristo y nos incorpora a sus miembros ${ }^{26}$.

\section{Valor de las analogías y comparaciones}

«La cuestión estriba - nos dice al fin del capítulo quinto- en saber de qué analogías y comparaciones nos servimos cuando creemos en Dios, a quien amamos sin conocerlo» ${ }^{27}$.

Parece plantear aquí san Agustín el verdadero objeto del libro octavo, introductorio a la segunda parte del gra tratado. Las analogías y comparaciones que empleará san Agustín serán tomadas de los seres de la creación, que son vestigios, huellas o imagen de Dios, mediante las cuales, por analogía, podemos conocer y amar a Dios, que es Trinidad. El proceso, profundamente pedagógico, lo comenta el mismo san Agustín al hacer la síntesis de lo expuesto en el libro quince ${ }^{28}$.

\section{Idea secundaria: Fe de san Agustín en la maternidad divina de María}

La razón profunda de esta maternidad la encuentra san Agustín en la cooperación de María en la obra redentora de Cristo. Es madre de Cristo «porque es madre de la humanidad que Cristo tomó por nosotros» ${ }^{29}$.

\section{Consecuencia fundamental del capítulo quinto:}

La imaginación puede fallar, la fe no falla jamás.

\section{CAPÍtUlo $7 .^{\circ}$ El AMOR, CAMINO SEgURO HACIA LA TRINIDAD}

El camino a seguir en la búsqueda y en la ordenación del amor es la propia interioridad, la persona misma, empeñada en cumplir incondicionalmente la voluntad de Dios.

26. «Noli quaerere intellegere ut credas, sed crede ut intellegas, quoniam nisi credideritis, non intellegetis». In Io Ev. tr. 29,6 PL 35,1630.

27. «Ex qua rerum notarum similitudinem vel comparatione credamus, quo etiam nondum notum Deum diligamus, hoc quaeritur", DT 8,5,8 PL 952.

28. $D T \cdot 15,3,5$ PL $1059-1060$.

29. DT 8,5,7 PL 952; v. In $J n$ ev. tr. 8,9 PL 35,1456; v. también ss. 291,6 PL 38,1319; 361,16 PL 39,1609. 
Puntos fundamentales:

\section{Definición del amor auténtico}

«Consiste en vivir justamente adheridos a la verdad y en despreciar todo lo perecedero por amor a los hombres, a quienes consideramos como hermanos) ${ }^{30}$.

Insiste san Agustín en centrar el tema y en aclarar conceptos sobre el amor. El mismo sintetiza toda la divina Escritura en el amor. Por eso nos dice en «De Doctrina christiana», como regla fundamental de hermenéutica: «El compendio de todo lo expuesto... entender que la esencia y el fin de toda la divina Escritura es el amor de la "Cosa» que hemos de gozar» ${ }^{31}$. La caridad compendia el contenido de su teología ${ }^{32}$ y el principio de la moral ${ }^{33}$, porque la moral cristiana se resume en el doble precepto de la caridad ${ }^{34}$. Todo ha de estar ordenado al amor, pues en el amor centra san Agustín la valoración ética de la misma persona. "Ama y haz lo que quieras; si callas, clamas, corriges, perdonas: calla, clama, corrige, perdona movido por la caridad. Dentro está la razón de la caridad, no puede brotar de ella mal alguno» ${ }^{35}$. El amor auténtico va siempre de Dios, al centro, a las criaturas, que tienen su última explicación en Dios ${ }^{36}$.

\section{Consecuencias:}

1. ${ }^{\mathrm{a}}$ Todo esto nos lleva $\mathrm{a}$ «estar preparados påra morir con granjería por los hermanos, a imitación de nuestro Señor Jesucristo, porque el que ama a Dios es lógico... que ame al prójimo, por ser este mandamiento de Dios» ${ }^{37}$. San Agustín busca que el amor a Dios y al prójimo se hallen en armonía.

30. «Haec est dilectio, ut inhaerentes veritati iuste vivamus; et ideo contemnamus omnia mortalia (temporalia) per amore hominum, quo eos volumus iuste vivere», DT 8,7,10 PL 956.

31. "Omnium igitur quae dicta sunt... haec summa est, ut intellegatur legis et omnium divinarum Scripturarum plenitudo et finis esse dilectio rei qua fruendum est», De doctr. christ. $1,35,39$ PL 34,34.

32. Cf. Ench. o de fide, spe et carit., todo él. PL 40,181-196.

33. Cf. De mor. eccl. cath. donde la moral cristiana se resume en el doble precepto del amor. PL 32,1309-1378.

34. Cf. P. TrAPE, Il Principio fondamentale della Spiritualita Agostiniana e la vita Monastica, Sanctus Augustinus Vitae Spiritualis Magister I, pp. 1-41, 1954.

35. «Dilege et quod vis fac; sive taceas... clames... emendes... parcas, radix sit intus dilectionis, non potest de ista radice nisi bonum existere", In Ep In tr. 7,8 PL 35,2033.

36. Cf. P. TRAPE, o.c., p. 37; cf. De mor. eccl. cath. 1,26,48 PL 32, 1331.

37. «et mori pro fratribus utiliter parati esse poterimus», DT 8,7,10 PL 956. 
2. ${ }^{\text {a }}$ Con una sola palabra expresa con frecuencia la divina Escritura los dos amores, «o sólo el amor a Dios... o sólo el amor al prójimo» ${ }^{38}$.

2. A Dios «se le halla en el interior, porque Dios es algo íntimo», "no se le halla en los prodigios» ${ }^{39}$, «porque Dios mora en nosotros» ${ }^{40}$.

Consecuencia:

Seguridad de la humildad para hallar a Dios. «Es más poderosa y más segura que las cimas barridas por los vientos... que las cimas de los cielos y que las profundidades de la tierra» ${ }^{41}$.

Busca san Agustín por todos los medios quitar todos los obstáculos, aclarar conceptos, centrar el tema del amor. Lo hace de modo progresivo hasta llegar àl último capítulo del libro.

\section{CAPÍTUlo $8 .^{\circ}$ El AMOR Verdadero VIENE DE DIOS Y ES DiOS}

El amor a Dios y el amor al hermano se halla en nuestro interior. Por tanto, con la mirada interior y al interior se ha de mirar para conocer la realidad del amor en nosotros. En el amor verdadero, además, se presencializa la Trinidad en nosotros.

\section{Puntos fundamentales:}

\section{El amor al hermano, signo del amor a Dios}

«Es más fácil conocer la dilección (Dios), que nos impulsa al amor, que al hermano a quien amamos. Se conoce más fácilmente el amor a Dios, porque es más presente, más interior, más cierto» ${ }^{42}$.

Y también:

«A Dios, que es caridad, podemos verlo con la mirada interior» ${ }^{43}$.

38. «plerumque Scriptura pro utroque unum ponit: sive tantum Dei... sive tantum proximi... commemorat», $D T$ 8,7,10 PL 956.

39. «interior est Deus... qui quaerunt Deum per istas potestates, quae mundo praesunt... auferuntur ab eo longe iactantur», DT 8,7,11 PL 957.

40. $D T$ ib.

41. «Potentior est enim et tutior solidissima humilitas, quam ventuosissima celsitudo», $D T$ $8,7,11$ PL 957.

42. «Magis enim novit dilectionem qua diligit, quam fratrem quem diligit... plane notiorem, quia presentiorem... quia interiorem... quia certiorem», DT 8,8,12 PL 957.

43. "visu interiore... videre potest», DT 8,8,12 PL 959 . 


\section{El amor, vínculo entre los hermanos y con Dios}

«Es el amor aquello que nos une con vínculo de santidad a todos los ángeles buenos y a todos los siervos de Dios; nos une a ellos y nos somete a Él» ${ }^{44}$.

El amor tiene una función medianera entre Dios, centro de todo amor verdadero, y el hombre, que participa de este amor. El amor imprime su peso y su gravitación hacia el centro de donde proviene.

En todo el proceso psicológico, ya desde el principio de esta segunda parte del tratado, san Agustín da importancia excepcional al amor. El amor interviene a todo lo largo de su especulación psicológica. El Verbo lleva consigo el amor mismo, y el amor, a su vez, va iluminado con la luz de aquél ${ }^{45}$.

3. Donde exista el amor verdadero se halla la Trinidad, se ve la Trinidad ${ }^{46}$, porque el amor viene de Dios

\section{El amor fraterno, es don de Dios y es Dios mismo ${ }^{47}$}

Aunque el Espíritu Santo es la Caridad en Dios y, por tanto, es la idea suprema de Caridad, lo es solamente por apropiación. Donde se halle caridad participada, puede decirse que se halla Dios, causa ejemplar y eficiente de toda caridad, pero sólo por participación.

\section{Orden que ha de tener nuestro amor}

— «A Dios hemos de amarle incomparablemente más que a nosotros mismos».

- «Al hermano, como a nosotros mismos»

— «Con un mismo amor de caridad amamos a Dios y al prójimo, pero a Dios por Dios, a nosotros y al prójimo por Dios» ${ }^{48}$.

44. «Ipsa dilectio quae omnes bonos angelos, et omnes Dei servos consociat vinculo sanctitatis, nosque et illos coniungit invicem nobis, et subiungit sibi», DT 8,8,12 PL 957.

45. «amat notitiam et novit amorem, et verbum in amore est, et amor in verbo», $D T$ 9,10,15 PL 969.

46. «eamdem ipsam fraternam dilectionem... non solum ex Deo, sed etiam Deus esse», $D T$ $8,8,12$ PL 958.

47. Cf. P. Argimiro TurRado, La Inhabitación de la Santísima Trinidad en los justos según la.doctrina de San Agustín», Augustinus Magister I, 1954, p. 587.

48. «Ex una eademque caritate Deum proximumque diligimus: sed Deum propter Deum, nos autem et proximum propter Deum», DT 8,8,12 PL 959 . 


\section{Consecuencias:}

$10^{2}$ - «La perfección radica en el amor al hermano» ${ }^{49}$.

2. ${ }^{\mathrm{a}}$ - «Cuando amamos al hermano en caridad cumplimos los dos preceptos: el amor al hermano y el amor a Dios», «porque aquellos dos preceptos no existen nunca el uno sin el otro», «porque si Dios es amor, ciertamente ama a Dios el que ama la caridad» ${ }^{50}$. En cambio: «Quien no ama al hermano no está en caridad... no está en Dios... porque Dios es amor" ${ }^{51}$.

$3^{2}{ }^{2}$ - Ni el amor al hermano ni el amor a nosotros mismos será auténtico, si no es un amor por Dios, «y cuanto más amemos a Dios más nos amamos a nosotros mismos» ${ }^{52}$.

Valoriza el amor toda la vida moral, porque «nuestras costumbres suelen juzgarse, no según lo que cada uno sabe, sino según lo que cada uno ama» ${ }^{53}$. Sólo el obrar en este orden produce la felicidad ${ }^{54}$.

\section{CAPÍTUlo $10 .^{\circ}$ VESTIGIOS DE LA TRINIDAD EN EL AMOR}

Hallamos dos cualidades fundamentales en el estilo de pensar de san Agustín: la penetración crítica y la tendencia a las explicaciones sencillas y universales ${ }^{55}$. El Obispo de Hipona, teólogo de la Trinidad, busca la imagen trinitaria en el hombre, pero es una búsqueda impregnada de amor. Ciertamente, es algo esencial el amor en san Agustín, en su vida y en toda su obra, de tal manera que no se explica su obra si no se la considera centrada en el amor. Termina el libro octavo con una reflexión de orientación sobre el amor.

\section{Puntos fundamentales:}

1. «La caridad es el amor del bien» 56

Recoge san Agustín esta definición de la Escritura. El bien auténtico perfecciona la voluntad, porque su objeto es ése precisamente, el bien, la bondad. Cuando ama algo, lo ama siempre como bien o bajo la apariencia de bien.

49. «Manifestum est quod iustitiae perfectionem in fratris dilectione posuerit» (Apostolus), $D T$ ib. PL 958.

50. «duo illa praecepta non posse esse sine invicem» $i b$.

51. ib.

52. «nos autem ipsos tanto magis diligimus, quanto magis diligimus Deum», $i b$. PL 959.

53. «Mores... non ex eo quod quisque novit, sed ex eo quod diligit, diiudicari solent», $E p$ $155,4,13$ PL 33,672.

54. «Nemo beatus est, nisi qui vivit in aeternum sine ullo timore, sine ulla fallacia», Sermo 150,10 PL 38,813.

55. Cf. Salvador Cuesta, La Concepción Agustiniana del Mundo a través del Amor, Augustinus Magister I, 1954, p. 347.

56. «Quid est autem dilectio vel caritas... nisi amor boni?», DT 8,10,14 PL 960. 
2. «El amor supone un amante y un objeto amado que se ama»

Por eso señala san Agustín, como indispensables, tres cosas en el amor: «el que ama, lo que se ama y el amor».

3. «El amor es vida que enlaza o ansía enlazar otras dos vidas», a saber, el amante y el amado».

Después de una digresión fugaz sobre el amor no recto, continúa: «Réstanos remontarnos aún más arriba y buscar en las cumbres estas tres realidades». Vislumbra ya aquí, en perspectiva panorámica, toda la segunda parte, cuya cima es la sabiduría, donde se halla la imagen verdadera de la Trinidad.

San Agustín halla en la reciprocidad humana del amor una analogía trinitaria. La unidad de corazones aquí abajo es, según él, una figura de la unidad más perfecta que existe entre las divinas Personas.

El Santo descarta siempre cuidadosamente las metáforas biológicas. Por ello dice: «¿Qué ama el alma en el amigo sino el alma? Aquí tenemos tres cosas: El amante, el amado y el amor» ${ }^{57}$. El amor intersubjetivo nos ofrece un vestigio de la Trinidad. De la fuerza de caridad que une los corazones, en un solo corazón, deduce san Agustín cómo será la fuente del amor en la Trinidad, a la que quiere ascender en su especulación en la segunda parte del tratado «De Trinitate».

«El amante, el amado y el amor» señala una jerarquización progresiva en las analogías de la Trinidad, que ocupan la segunda parte del gran tratado.

\section{CONSECUENCIA FINAL}

San Agustín quisiera continuar. Nos lo dice: «Réstanos remontarnos aún más arriba y buscar en las cumbres estas tres realidades, en la medida otorgada al hombre», pero se detiene de momento y no continúa: «Descanse aquí un momento nuestra atención»... «porque hemos topado ya con el soto donde es menester buscar» ${ }^{58}$.

Detiene aquí san Agustín su búsqueda fatigosa. Ha hecho una prueba introductoria larga, la ha hecho para sus lectores, sabe que es difícil sostener su atención y por ello, habiendo encontrado el campo donde se halla el tesoro que busca -el alma espiritual en su actividad del amor, como imagen de la Trinidad divina - se detiene por unos momentos para remontar su vuelo de

57. Cf. el artículo de Maurice Nédoncelle, L'intersubjetivité humaine est-elle pour saint Augustin une image de la Trinité? Augustinus Magister I, 1954, pp. 599-602.

58. «Sed hic paululum requiescat intentio», DT 8,10,14 PL 960. 
nuevo. De hecho, esto significan las palabras finales del capítulo: «Que esto baste y sirva de exordio a cuanto en lo sucesivo hayamos de entretejer» ${ }^{59}$.

Seguirá san Agustín su búsqueda afanosa, en un orden progresivo, deteniéndose cuando vea fatigados a sus lectores, como lo hará en el libro undécimo, para emprender de nuevo el vuelo hasta la cima. Ha sido un ejercicio práctico el que ha querido realizar en este libro octavo que, en síntesis, comprende el método psicológico que va a seguir en la segunda parte del tratado «De Trinitate».

\section{CONCLUSIÓN-RESUMEN}

Precede al tema el plan general de todo el trabajo a realizar, en el que se puede apreciar, de un solo golpe de vista, el método a seguir y el desarrollo que ha de tener el estudio.

La introducción estudia la razón del tratado «De Trinitate». Las vicisitudes que tuvo san Agustín en su composición influyeron en la misma obra. Un espacio aproximado de unos veinte años separa el comienzo de su publicación definitiva, pues el mismo santo Doctor nos dice en la carta-prólogo 174: «Joven aún (c. 399), di principio a estos mis libros sobre la Trinidad, que es Dios sumo y verdadero, y en mi ancianidad los publiqué (c. 420). Explica también cómo esto influye en el ánimo de san Agustín, que debe acomodar los últimos libros del gran tratado a los que había compuesto en su juventud.

Subraya asimismo la introducción que la razón fundamental de la composición del tratado «De Trinitate» se halla en el ánimo mismo de san Agustín, psicólogo, teólogo y místico.

Consideré también necesario hacer un breve esquema de todo el tratado «De Trinitate», porque el libro octavo, argumento de mi estudio, se halla enclavado en el centro del mismo tratado, como libro de enlace entre la primera y la segunda parte, y este resumen ayuda, sin duda, a comprender, en síntesis, el papel que ocupa el libro octavo en toda la obra. Por medio de este esquema, en efecto, se puede apreciar fácilmente el desarrollo de todo el tratado, especialmente el desarrollo de la segunda parte.

En el breve resumen del tratado «De Trinitate», los libros de la primera parte, en líneas generales, se hallan resumidos de manera un tanto más extensa que los libros de la segunda parte, porque estos últimos se explican de nuevo en el capítulo segundo de la primera parte, en sus aspectos psicológico, teoló-

59. «...ita hoc dixisse suffecerit, ut tanquam ab articulo alicuius exordii cetera contexamus», $D T$ 8,10,14 PL 960. 
gico y místico, especialmente en lo relativo a la imagen de Dios en el alma, tema principal de toda la segunda parte. El capítulo quince de este resumen, no obstante, tiene mayor extensión, por su importancia excepcional, como resumen de todo el tratado «De Trinitate». A la breve síntesis de cada uno de los libros, precede una frase que, a mi parecer, expresa, en síntesis, la característica principal del mismo libro.

En la primera parte, el capítulo primero: «Inserción del libro octavo en el tratado «De Trinitate», «Razones de esta inserción», tiene excepcional importancia. En este capítulo he aportado algunas razones que, a mi juicio, explican suficientemente por qué san Agustín escribe este libro antes de comenzar la segunda parte del gran tratado.

No conozco ningún resumen de por qué san Agustín inserta este libro, con las características que presenta, entre la primera y la segunda parte del tratado «De Trinitate». De hecho, el libro octavo, se halla enclavado exactamente en el medio, es decir: después de la primera parte, positiva, los siete primeros libros, $y$ antes de la segunda parte, especulativa, los siete últimos libros del gran tratado. Por ello, la elaboración de este capítulo ha implicado especial dificultad para mí por ser totalmente original. Explica este capítulo cómo san Agustín quiere exponer el método que ha de seguir en la segunda parte, coherente con su pensamiento, que orienta siempre la filosofía a la teología y la teología al conocimiento y vivencia mística de Dios.

El santo Doctor quiere hacer notar que va a emplear una nomenclatura diversa, propia suya, idéntica en algunos casos en las expresiones ya conocidas, pero en la que las palabras tienen significado distinto. Sencillamente quiere darnos una perspectiva de su método a seguir, llevando como de la mano a sus lectores, en este proceso de ascensión hacia Dios Trinidad.

El capítulo segundo: «Imagen de la Trinidad en el alma», expone algunos conceptos básicos indispensables, para comprender cómo el alma, por ser espiritual, es imagen de Dios.

$\mathrm{El}$ artículo primero: «Aspecto psicológico», tiene gran extensión, porque el concepto más rico de la segunda parte es la especulación psicológica, en la que san Agustín explica cómo el alma es imagen de Dios en su espiritualidad superior y en sus actividades espirituales. Lo referente al concepto de imagen se halla aquí más extenso por este motivo.

El artículo segundo: «Aspecto teológico», explica, primordialmente, cómo una de las mayores dificultades que preocupa a san Agustín durante todo el tratado - la procedencia del Espíritu Santo y por qué no es imagen - la va desarrollando gradualmente: propone la dificultad en los libros primero y segundo, hace una leve sugerencia en el libro quinto, anota una pequeña solu- 
ción en el libro noveno y solamente en el libro quince, ya casi al final de la obra, presenta su opinión definitiva.

El artículo tercero: «Aspecto místico», explica especialmente los conceptos de piedad y plegaria, que impregnan toda la obra; la primacía de la interioridad, que se halla en todas las obras de san Agustín; la sabiduría y la contemplación; el proceso de transformación, que comienza en el bautismo, como fruto de la redención de Cristo, y tiene su despliegue final en la visión contemplativa de Dios.

Subraya también este artículo cómo san Agustín no pudo escribir el tratado «De Trinitate», especialmente la segunda parte, sin tener en sí mismo una vivencia profunda y mística de Dios. Termina el aspecto místico con una reflexión sobre la deificación mística, que es la síntesis de todo el cristianismo.

Los tres artículos citados, aparecen especificados en algunos puntos concretos más salientes, para facilitar su comprensión.

En la segunda parte, el capítulo primero: «Síntesis global del libro octavo", presenta brevemente lo que va a exponer esta segunda parte de mi estudio. En su brevedad, puede apreciarse fácilmente el orden progresivo y coherente del libro octavo.

El capítulo segundo: «Conocimiento místico de Dios», es una breve orientación. Expone este capítulo cómo san Agustín, en la segunda parte, quiere más bien mostrar a Dios que demostrarle, y cómo la misma plegaria final del tratado nos hace ver la acentuación mística de toda la obra, especialmente de la segunda parte.

Previa la orientación anterior, continúa el estudio especial sobre el libro octavo. Precede un resumen de todo el libro, un resumen esquemático solamente, que facilita la comprensión sobre el conocimiento místico de Dios por los conceptos de Verdad, Bondad, Justicia y Caridad.

El prólogo aparece como una especie de enlace entre la primera parte del tratado «De Trinitate» y el libro octavo propiamente dicho: «Diximus», «dicimus» = «dijimos», «decimos», etc. Explica también el prólogo cómo desde aquí comienza el «modo interiore», el modo más profundo de estudiar la presencia de la Trinidad en el alma y cómo esta especulación psicológica debe tener siempre como orientación la «regla de la fe».

Los puntos especialmente subrayados, intentan hacer fijar la atención en aquello que considero específico de la segunda parte, desde el libro octavo hasta el final del tratado «De Trinitate».

Al conocimiento místico de Dios por los conceptos de «Verdad, Bondad, Justicia y Caridad», precede un breve esquema específico, que resume las ideas fundamentales de cada uno de los capítulos que estudian dichos conceptos. 
El «concepto de Verdad» tiene mayor extensión que los conceptos de «Bondad» y de «Justicia» porque san Agustín también se la da. Este concepto abarca dos capítulos, primero y segundo del libro octavo y explica cómo, según la mente del santo Doctor, la Verdad es el mismo Dios, es el Verbo, causa eficiente de la creación. Dios es verdad y es luz. Explica también cómo ninguna imagen es apta para llevarnos a la Verdad. Examina también este apartado cómo el concepto de verdad se halla en la propia interioridad y cómo no se puede desconocer.

El «concepto de Bondad» ocupa el capítulo tercero del libro octavo. Muestra este concepto cómo Dios es Bien simplicísimo, cómo se debe amar por sí mismo, cómo la bondad de los bienes creados procede del bien absoluto y cómo, finalmente, la felicidad última se consigue al contemplar el Bien sumo.

El «concepto de Justicia» lo expone san Agustín en los capítulos sexto y noveno del libro octavo. Explica este apartado cómo para el Santo la justicia radica en el alma; cómo la justicia cristiana es una forma de amor y de caridad; cómo la justicia es la santidad y realiza toda la perfección. Es más, prueba este concepto cómo san Agustín llega a identificar justicia y caridad: «La caridad incoada, nos dice, es la justicia incoada, la caridad avanzada es justicia avanzada y la caridad perfecta es la justicia perfecta». Por esto la justicia, en su plenitud, se realizará únicamente en el cielo.

Explica también este apartado cómo para san Agustín la Justicia, la Verdad y el Bien radican en el alma y se conocen en el interior.

Un brevísimo resumen previo a cada uno de los conceptos de «Verdad, Bondad y Justicia», a los capítulos que estudian estos conceptos, las ideas fundamentales especialmente señaladas y las consecuencias que de ellas se deducen, quieren hacer fijar la atención del lector en lo que puede considerarse el meollo de la argumentación agustiniana en su intento de llevarnos al conocimiento místico y a la contemplación de Dios por medio de estos conceptos.

El «concepto de Caridad», el más importante, el más complejo y el más extensamente tratado por san Agustín en el libro octavo, ocupa también la parte más extensa de mi estudio. A encontrar la imagen de la Trinidad en el amor se orienta, al fin de cuentas, la reflexión psicológico-teológica de san Agustín. El santo Doctor se ocupa de este tema en los capítulos cuarto, quinto, séptimo, octavo y décimo del libro octavo del tratado «De Trinitate».

Al conocimiento místico de Dios por el «concepto de Caridad», como en los conceptos anteriores de Verdad, Bondad y Justicia, precede un esquema de conjunto. En este esquema previo, se anotan: las ideas principales y las consecuencias que se deducen de ellas, ideas y consecuencias que, a mi parecer, reflejan el contenido fundamental de los cinco capítulos del libro octavo que 
tratan de este tema. A su vez, a cada uno de estos capítulos, precede también una pequeña síntesis de su contenido específico, en el marco global del conocimiento místico de Dios por el amor.

El capítulo cuarto trata de la fe como preámbulo del amor. Explica este capítulo cómo la fe recta, no fingida, no falla jamás y cómo ninguna imagen puede representar la Trinidad. La fe, en cambio, nos lleva al conocimiento y al amor de Dios Trinidad. Finaliza el estudio sobre la fe afirmando la necesidad de purificar los corazones y de prepararlos para la visión. La visión es el premio de la fe verdadera.

El capítulo quinto explica cómo nuestros razonamientos se orientan siempre por los primeros principios, ideas injertadas en la misma naturaleza humana; el papel de la humildad y de la fe en el amor a la Trinidad y el valor de las analogías y comparaciones en todo este proceso.

El capítulo séptimo expone, en síntesis, cómo el amor conduce al conocimiento de la Trinidad, la definición del amor auténtico y cómo a Dios se le ha de hallar, no en los prodigios, sino en la intimidad del corazón, porque Dios mora en nosotros.

El capítulo octavo explica cómo el amor verdadero viene de Dios y es Dios mismo, cómo es el vínculo de unión entre los hermanos, cómo dónde hay amor se halla la Trinidad y qué orden se ha de seguir en la práctica de nuestro amor.

Finalmente, el capítulo décimo presenta los vestigios de la Trinidad en el amor y cómo el amor supone un amante, un objeto amado que se ama y el amor mismo. Se dan, por tanto, en el amor las tres realidades, que son vida y enlaza o ansía enlazar otras dos vidas: «El amante, el amado y el amor», que las une.

Al llegar a este punto san Agustín quisiera subir, ascender más: «Réstanos remontarnos aún más arriba», pero se detiene y comenta: «Descanse aquí un momento nuestra atención... porque hemos topado ya con el soto donde es menester buscar». Seguirá la búsqueda afanosa, pero ahora es menester detenerse y reposar antes de continuar el ascenso.

Las últimas palabras aducidas en este último capítulo son las mismas que aduce el santo al llegar al final de este ensayo, de este entrenamiento, para poder continuar en la búsqueda de la imagen de la Trinidad en el alma. Dice, en efecto, al final del libro octavo: «que esto baste y sirva de exordio a cuanto en lo sucesivo hayamos de entretejer».

El texto español del tratado «De Trinitate» lo he tomado de la versión del P. Luis Arias: «Tratado sobre la Santísima Trinidad», BAC 39 (V) segunda y cuarta edición, 1956 y 1985 respectivamente. 
Con frecuencia, los textos tomados del tratado «De Trinitate» llevan su nota correspondiente en latín o al menos las palabras claves del texto anotado en español. Las demás notas, en cambio, solamente llevan la anotación del lugar correspondiente donde se han tomado, bien sea textualmente, en cuyo caso se hace la anotación entre comillas en el texto, o bien al sentido y entonces llevan solamente el número y lugar correspondiente de donde se han tomado.

La bibliografía general empleada y las obras estudiadas o citadas de san Agustín van al final del estudio. 


\section{BIBLIOGRAFÍA}

ALCORTA, José Ignacio, El conocimiento divino según san Agustín, Augustinus III, 1958, pp. 309-321.

- La imagen de Dios en el hombre, según san Agustín, Augustinus XII, 1967, p. 29-38.

ALLERS, Rudolff, Les idées de triade et de médiation dans la pensée de saint Augustin, Augustinus III, 1958, pp. 247-254.

- Ilumination et verités éternelles, Augustinus Magister I, 1954, pp. 477-490.

AMBROSIO, S., De officiis ministrorum, PL 16,24-194.

ANTONELLI, María Teresa, La dialletica dell'uomo interiore in S. Agostino, Humanitas II, 1954, pp. 990-1012.

- Aspetti agostiniani del problema del filosofare, Augustinus Magister I, 1954, pp. 335-346.

ARIAS, Luis, Introducción, Obras de san Agustín, BAC, V, Tratado sobre la Santísima Trinidad, segunda edición, 1956, pp. 3-121 y cuarta edición, 1985.

BLANCHARD, Pierre, L'espace intérieur chez saint Augustin, d'après le libre $X$ des Confessions, Augustinus Magister I, 1954, pp. 535-542.

BOYER, Carlo, La dottrina dell'Incarnazione nella spiritualitd di S. Agostino, S. Augustinus, Vitae Spiritualis Magister I, 1956, pp. 103-112.

BOYER, Charles, Les vois de la connaissance de Dieu selon saint Augustin, Augustinus III, 1958, pp. 303-307.

-L'image de la Trinité syntèse de la pensée augustinienne, Gregorianum XXVII, pp. 173-199 y 333-352.

CABA, Pedro, La Filosofía del conocimiento en san Agustín, Augustinus III, 1958, pp. 215-226.

CAPÁNAGA, Victorino, Introducción General, Obras de san Agustín, BAC I, 5. ${ }^{a}$ edición, 1979, pp. 1-292.

- Conocimiento y espiritu según san Agustín, Augustinus III, pp. 177-191.

- La doctrina agustiniana sobre la intuición, Religión y Cultura 15 (1931), pp. 8-109.

- La interioridad agustiniana, Augustinus III, 1958, pp, 13-26.

- San Agustín en nuestro tiempo, la interioridad agustiniana, Augustinus I, 1956, pp. 201-213.

- La deificación en la soteriología agustiniana, Augustinus II, 1954, pp. 1-121.

CAMPENHAUSEN, v. Hans, Les Pères Latins, traduit de l'allemand par C. Moreau de l'Orante, Paris 1967.

CAYRÉ, Fulbert, La contemplation Augustinienne, Principes de Spiritualité et de Théologie, 1974.

-Dieu présent dans la vie de l'esprit, 1951.

-Notion de la mystique d'après les grandes traités de saint Augustin, Augustinus Magister II, 1954, pp. 606-622.

— «Alta Sapienza e Vita Cristiana, Sanctus Augustinus Vitae Spiritualis Magister I, 1956, pp. $77-$ 101.

CEPEDA CALZADA, Pablo, El retorno del alma en la vía mística, Augustinus Magister I, 1954, pp. 499-509.

CICERÓN, Hortens., fragm. 19 (ed. Müller).

CILlERUELO, Lope, La Memoria Dei, según San Agustín, Augustinus Magister I, 1954, pp. 499-509.

— ¿Por qué «Memoria Dei» Revue des Études Augustiniennes X, 1964, pp. 289-294.

-Caratteri del Monacato Agostiniano, Sanctus Augustinus Vitae Spiritualis Magister I, 1956, pp. 43-75.

- Teología Espiritual I. Ordo Amoris (separata), Estudio Agustiniano, Valladolid 1976.

CUESTA, Salvador, La concepción agustiniana del mundo a través del amor, Augustinus Magister I, 1954, pp. 347-356. 
CUSTODIO VEGA, Ángel, San Agustín y la filosofía nueva, Augustinus Magister I, 1954, pp. 389-402.

FLORENTINO, Conc., Decr. pro Iacobitis, Denz. 703 y 1330.

FLÓREZ, Ramiro, Puntos para una antropología agustiniana, Augustinus Magister I, 1954, pp. 551-557.

GONZÁLEZ, Eugenio, El concepto y método de la teología en «De Trinitate» de san Agustín, Augustinus I, 1956, pp. 379-398.

GONZÁLEZ, Sergio, «La preocupación arriana en la predicación de San Agustín. Tratados sobre el Evangelio y $1 .^{a}$ Epístola de San Juan, Enarraciones sobre los Salmos, Sermones al Pueblo», Estudio Agustiniano, Valladolid 1989.

GRABOWSKI, Estanislao, La fe en el Cuerpo místico de Cristo, según san Agustín, Augustinus I, 1956, pp. 539-557.

HENDRIKX, E., Introduction, Oeuvres de saint Augustin, 15, 1955, 2. a série: Dieu et son Oeuvre, «La Trinité», pp. 7-76.

LA BONNARDIÈRE, A.M:, Recherches de chronologie augustinienne, Paris 1965, pp. 165177.

-Les images de la Trinité. Anné theol. Augusti. 1953. fsc. III-IV.

MADEC, G., Pour ou contre la «Memoria Dei», REAug. 11, 1965, pp. 89-92.

MARKUS, R.A., «Imago» and «similitudo» in Augustine, Revue des Études Augustiniennes X, 1964, pp. 125-143.

MORÁN, José, Las relaciones divinas, según san Agustín, Augustinus IV, 1959, pp. 353-372.

MUÑOZ ALONSO, Adolfo, Intellectum valde ama, Augustinus III, 1958, pp. 171-176.

MUÑOZ VEGA, Pablo, Los problemas de la experiencia mística a la luz del pensamiento agustiniano, Augustinus Magister I, 1954, pp. 603-607.

NEDONCELLE, Maurice, L'intersujectivié humaine est-elle pour Saint Augustin une image de la Trinité?, Augustinus Magister I, 1954, pp. 595-602.

OCCHIALINI, Umberto, La Speranza della Chiesa Pellegrina», Assisi 1965.

OLTRA, Miguel, Cómo se conoce la revelación sobrenatural según san Agustín, Augustinus III, 1958, pp. 281-289.

PLOTINO, Ennéadas, V.

QUILES, Ismael, Para una interpretación integral de la iluminación agustiniana, Augustinus III, 1958, pp. 255-268.

ROHMER, Jean, L'intentionalité des sensations chez saint Augustin, Augustinus Magister I, 1954, pp. 491-498.

SCANO, Efisio, Il cristocentrismo e $i$ suoi fondamenti dommatici in S. Agostino, Torino, 1951.

SCHMAUS, M., Die psychologische Trinitätslehre des hl. Augustinus, Münster i.W. 1927.

SCIACCA, Michele Federico, Introduzione filosofica, al De Trinitate», Opera omnia di S. Agostino, Vol. IV, Roma 1973, pp. LXVII-CXIV.

- Il principio della metafisica di $S$. Agostino e tentativi metafisici del pensiero moderno, Humanitas II, 1954, pp. 947-958.

- Trinité et unité de l'esprit, Augustinus Magister I, 1954, 521-533.

- Símbolo de los Apóstoles DB 1-13.

- Símbolo Niceno, DB 54.

SOLIGNAC, Aimé, Le libre $X$ des Confessions. Lectio Augustini. Settimana Agostiniana Pavese. Ed. Augustinus. Palermo, 1987.

SOMERS, Hernán, Image de Dieu et illumination divine. Aug. Mag. I, 1954, pp. 451-462.

STEFANINI, Luigi, El problema de la persona en S. Agustín en el pensamiento contemporáneo, Augustinus I, 1956, pp. 139-152 (traduc. por Fr. Luis Garagoa).

STUDER, Basile, Le Christ, nostre justice, selon saint Augustin, Augustinus XXVI, 1981, pp. 253-282 (traduc. por M. Bueno y J. Oroz).

THONNARD, François-Joseph, San Agustín y Luis Lavalle. La actualidad de la filosofía de san Agustín, Augustinus I, 1956, pp. 23-32. (traduc. por Fr. J. Oroz). 
- Caractères platoniciens de l'ontologie augustinienne, Augustinus Magister I, 1954, pp. 317327.

- Justice de Dieu et justice humaine selon saint Augustin, Augustinus XII, 1967, pp. 387-402.

TRAPÈ, Agostino, Introduzione Teologica, al De Trinitate, Opera omnia di S. Agostino, vol. IV, Roma 1973, pp. VII-LXV.

-S. Agostino, L'Uomo, il Pastore, il Mistico, 1976, capitolo XXXIV especialmente.

- Il principio fondamentale della spiritualitá agostiniana e la vita monastica, Sanctus Augustinus, Vitae Spiritualis Magister I, 1956, pp. 1-41.

- Nota sulla processione dello Spirito Santo nella Teologia Trinitaria di S. Agostino e di S. Tommaso, Studi Tomistici, 1, pp. 119-125.

TREMBLAY, Richard, Les processions du verbe et de l'amour humains chez saint Augustin, Revue de l'Université d'Ottawa, XXIV 1954, 93-117.

- La théorie psycologique de la Trinité chez St. Augustine, Etudes et Recherches 8,1952, pp. 83109.

TURRADO, Argimiro, La Santísima Trinidad en la vida espiritual del justo, su templo vivo, según san Agustín, Revue des Etudes Augustiniennes V-VI, 1959, pp. 129-151 (primera parte), y 223-260 (segunda parte).

- La inhabitación de la Santísima Trinidad en los justos según la doctrina de san Agustín, Augustinus Magister, I, 1954, pp. 583-593.

- Nuestra imagen y semejanza divina. En torno a la evolución de esta doctrina en san Agustin, La Ciudad de Dios 181, 1968, pp. 776-801.

WINKLER, Klaus, La théorie augustinienne de la mémoire a son point de départ, Augustinus Magister I, 1954, pp. 511-519. 


\section{OBRAS DE SAN AGUSTÍN CITADAS EN ESTE ESTUDIO}

- Contra Academicos,

- De agone christiano,

- De anima et eius origine,

- De civitate Dei,

- Confessiones,

- De doctrina christiana,

- Enchiridion ad Laurentium, vel De fide, spe et charitate,

-Epp. 11, 102, 120, 137, 140, 147, 155, 169, 174, 185, 221-224,

- Contra duas epistolas Pelagianorum,

-Enarrationes in Psalmos: 14, 30, 33, 42, 57, 118, 130, 134, 139, 144,

- De fide et symbolo,

-De Genesi ad litteram,

- De Genesi ad litteram liber imperfectus,

-De haeresibus,

- De libero arbitrio,

-De magistro,

- Contra Maximum arianum, liber $I_{s}$

- De moribus ecclesiae catholicae et Manichaeorum,

- De natura et gratia,

- De perfectione iustitiae hominis,

- De ordine,

- De peccatorum meritis et remissione et de baptismo parvulorum libri III,

- De praedestinatione sanctorum et De dono perseverantiae,

- De sermone Domini in monte, libri II,

- Quaestiones in Heptateucum,

- Retractationes,

- Sermones: $38,52,103,144,150,179,192,291,361$,

- Soliloquia,

-In Ioannis Evangelium tractatus: 3, 8, 19, 21, 22, 29, 53,

-In Epistolam Ioannis ad Parthos tractatus: 7,

- De Trinitate,

- De vera religione. 